\title{
A Garden Variety of UCC Issues Dealing with Agriculture
}

Keith G. Meyer ${ }^{*}$

I. INTRODUCTION 1120

II. SCOPE 1122

A. In General 1122

B. Scope Issues Regarding Agricultural Credit 1127

C. Miscellaneous Scope Issues 1133

III. PERFECTION 1134

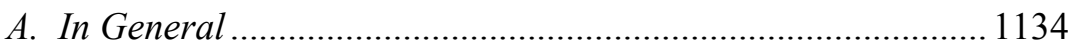

B. Certificate of Title Collateral................................................ 1135

IV. PERFECTED SECURED CREDITORS VERSUS BuyERS OF NON-FARM PRODUCTS 1142

V. BUYERS OF GOODS FROM MERCHANTS WHO SELL

GOODS ENTRUSTED TO THEM. 1146

VI. PURCHASE OF FARM PRODUCTS SUBJECT TO A PERFECTED SECURITY INTEREST. 1152

VII. SALE OF FARM PRODUCTS SUBJECT TO A PSI NOT CREATED BY SELLER 1160

VIII. SALE OF FARM PRODUCTS SUBJECT TO AN UNPERFECTED SECURITY INTEREST.

IX. PURCHASERS OF FARM PRODUCTS AND

AGRICULTURAL LIENS ... 1174

A. Section 1631 and Agricultural Liens Under the UCC 1174

B. Kansas's Approach to Sale of Farm Products Subject to a Statutory Lien 1175

* E.S. and Tom W. Hampton Professor of Law, University of Kansas. B.A., Cornell College, 1964; J.D., University of Iowa, 1967. Professor Meyer wishes to thank Nathaniel Hill for his excellent research and editing assistance. 


\section{INTRODUCTION}

Producers, lenders, lawyers, and courts continue to grapple with problems connected with agriculture credit. This Article will examine a few of the unique issues agricultural collateral transactions raise with Article 9 of the Uniform Commercial Code (UCC), ${ }^{1}$ as well as some interesting problems dealing with purchasers of farm products subject to a security interest, and farm products sold by someone other than the rightful owner of the goods.

In 1962, the UCC included Article 9 which governs conflicts concerning security interests in personal property. Since 1962, Article 9 has been changed significantly twice. Substantial amendments were made in 1972, and in 1999, Article 9 was completely revised. The 1999 version is often called "Revised 9" and is the product of years of study and drafting by the National Conference of Commissioners on Uniform State Laws (NCCUSL) ${ }^{2}$ and the American Law Institute (ALI). ${ }^{3}$ The

1. Unless otherwise indicated all citations in this paper are to the 2009 version of the UCC found in Selected Commercial Statutes (Carol L. Chomsky et al. eds., West 2009). The Kansas version of Article 9 is found in sections 84-9-101 to 700 of the 1984 Kansas Statutes and the 2008 Supplement.

2. See generally Uniform Law Commission, http://www.nccusl.org/Update/ (last visited Mar. 3, 2010). The NCCUSL is an organization of state governments started in 1892 whose purpose is to draft and secure enactment of uniform state laws on a wide variety of subjects. The NCCUSL became interested in developing a single comprehensive commercial code covering all aspects of commercial transactions (contract, payment, and credit). It drafts two types of proposed legislation: (1) uniform acts which apply to legal problems common to all states, where uniformity of treatment is very important; and (2) model acts which involve problems common to all states, but where uniformity is not important.

Members who serve without compensation are called commissioners and come from all fifty states plus the District of Columbia, Puerto Rico, and the Virgin Islands. Most are practicing lawyers, but some are judges and law professors. Each state normally sends four people. Each state's delegation, however, has only one vote on whether proposed acts should be approved by the NCCUSL. Each commissioner must try to persuade his or her state legislature to adopt its proposals.

An established process exists for determining when the NCCUSL will get involved. Initially, a study committee of commissioners will be formed. This function is performed by the Permanent Editorial Board (PEB) when an area covered by the UCC is involved. Suggestions for changes can come from the PEB, individual commissioners, the ALI or its members, and third parties such as the American Bar Association (ABA). Once the Executive Committee of the NCCUSL and the ALI decide to proceed, a drafting committee is formed. This committee will have a reporter who is a legal expert in the subject matter of the proposed statute. The product of the drafting committee is presented and must be approved by the membership of the NCCUSL and also by the ALI membership when the UCC is involved. For a general discussion of the process, see infra text of note 4.

3. The ALI has about 2500 members (professors, judges, and practicing lawyers) who are elected for life. It is funded by gifts, dues, receipts from the sale of publications, and returns on investments. The NCCUSL conceived the idea of a UCC and sought the help of the ALI who has a wider membership, greater prestige, and more financial support. The ALI has formulated a comprehensive series of restatements of common law. The ALI has been involved with codification 
revision process followed in revising Article 9 is not without controversy. ${ }^{4}$ However, somewhat surprisingly, all states quickly adopted some version of Revised Article 9. ${ }^{5}$ Article 9 has a language all its own $^{6}$ and is basically divided into five parts: scope, ${ }^{7}$ attachment, ${ }^{8}$ perfection, ${ }^{9}$ priorities, ${ }^{10}$ and default. ${ }^{11}$ This Article will be organized around the first four parts.

projects, model acts, and studies.

4. Questions have been raised about the process followed by the NCCUSL and the ALI in revising Article 9. Moreover, only time will tell whether Revised 9 will produce results that justify the considerable resources devoted to its creation and the costs connected with implementing Revised 9. Previous drafts of Revised 9 may be found on the Internet at University of Pennsylvania Law School, http://www.law.upenn.edu/bll/archives/ulc/ulc.htm (last visited Mar. 10, 2010).

Both NCCUSL and ALI work on revisions and both approve changes, but the NCCUSL alone directs the effort to get states to adopt the new version of the UCC. The ALI revision process typically starts with a study committee and a group of advisors. If changes are needed, a drafting committee is appointed. The drafting committee will contain academics, representatives of the various industries affected and consumer advocates. An attempt is made to develop a code that has broad appeal so that special interest groups will not derail states from adopting it. It must also be noted that currently the ABA plays an important role in the development process. For a thorough discussion of the revision process of Article 9 of the UCC, see Marianne B. Culhane, The UCC Revision Process: Legislation You Should See in the Making, 26 CREIGHTON L. REV. 29 (1992).

Some have argued that the process is a closed society dominated by pro-business advocates and is too rigid in its approach to rethinking uniform acts. See Kathleen Patchel, Interest Group Politics, Federalism, and the Uniform Laws Process: Some Lessons from the Uniform Commercial Code, 78 MinN. L. REV. 83 (1993); Edward L. Rubin, Thinking Like a Lawyer, Acting Like a Lobbyist: Some Notes on the Process of Revising UCC Articles 3 and 4, 26 LOY. L.A. L. REV. 743 (1993); Alan Schwartz \& Robert E. Scott, The Political Economy of Private Legislatures, 143 U. PA. L. REV. 595 (1995).

5. See 1998 UCC Article 9 Revision, in 1 Secured Transactions Guide 4991 (Commerce Clearing House, Inc., 2002) (listing dates of states' adoption of the 1998 Article 9 text).

6. Article 9's language is unique and defines terms in a unique way. The person granting credit may become a "secured party" by contracting for a "security interest" in property called "collateral" to secure an obligation of the "debtor." See U.C.C. § 9-102(a)(72) (defining "secured party"); § 9-102(a)(12) (defining "collateral"); § 9-102(a)(28) (defining "debtor"). The contract is a "security agreement." §9-102(a)(73). "Security interest" is defined as "an interest in personal property or fixtures which secures payment or performance of an obligation." $§ 1-201(35)$.

7. $\S 9-109$.

8. $\S \S 9-201$ to 210 .

9. Perfection is designed to give public notice of a security interest. $\S \S 9-308$ to $316,9-502$ cmt. 2. In general, depending on the type of collateral, perfection can occur in five different ways: (1) secured party files a financing statement in a public office, (2) secured party takes possession of the collateral, (3) secured party obtains control, (4) the security interest is noted on the certificate of title, and (5) perfection can occur automatically upon attachment of the security interest under $\S 9$ 203(b). §§9-310 to 316.

10. See $\S \S 9-317$ to 339 .

11. $\S \S 9-601$ to 624 . 


\section{SCOPE}

\section{A. In General}

When a debtor defaults on its obligation to a creditor, the question becomes how the creditor will collect on its debt. This turns on whether the creditor is secured or unsecured. Secured, in general, means that the creditor has an enforceable lien on specific property of the debtor. Liens can exist in personal property as well as in real property. In general, a lien on specific property may be obtained in three ways: a judicial lien, ${ }^{12}$ a statutory lien, ${ }^{13}$ or a consensual lien. Article 9 basically covers only consensual liens. In other words, those transactions where a debtor by agreement grants to a creditor an enforceable interest in specific property to secure debtor's obligation to pay or perform are covered.

What does it mean to say that a conflict or transaction is covered by Article 9? Unless otherwise provided, it means that all of the attachment, perfection, priority, default and enforcement rules apply. Whether Article 9 applies is important when parties are considering some sort of credit transaction and when an existing credit transaction has difficulties.

12. A judicial lien is normally created through the litigation process when the creditor seeks a money judgment on an unpaid debt. Upon obtaining a judgment, the creditor enforces the judgment by properly taking control of the property and converting it to cash. State enforcement mechanisms and exemptions differ. Once the creditor has taken control of personal property, the creditor is a lien creditor for purposes of Article 9. U.C.C. § 9-102(a)(52)(A) (2009).

13. Statutory liens are not created by agreement and do not depend upon judicial action. It is a "status lien" - arising by operation of law because of a particular creditor's status. The statutory lien gives a creditor an enforceable interest in specific goods to assure payment for goods, services, land, labor, or whatever was provided by the person entitled to the lien. Of course the property normally has to be converted to cash. Statutory lien holders are, in effect, given the rights of a secured creditor even though they did not bargain for security. Statutory liens are either possessory or nonpossessory. If a lien is possessory, the creditor claiming the lien must have possession of the property claimed to be subject to the lien.

Traditionally, non-consensual liens created in personal property by statute have not been covered by Article 9. However, the uniform version of Article 9 does cover two statutory liens. One is a priority conflict between a secured creditor and the holder of a possessory statutory lien. See U.C.C. $\S 9-333$ (2009). The other is a statutory agriculture lien. See $\S \S 9-102$ (a)(5), 9-109 (a)(2).

One of the most significant revisions of Article 9 in 2001 concerns nonpossessory liens in agricultural products. This change has been enacted in every state other than Kansas. For the first time, a nonpossessory statutory lien defined as an "agriculture lien" is subject to Article 9's perfection, priority, and enforcement rules. Id. A number of law review articles examine agricultural financing and liens under Revised 9. See, e.g., Keith G. Meyer, Kansas's Unique Treatment of Agricultural Liens, 53 U. KAN. L. REV. 1141 (2005) [hereinafter Meyer, Unique Treatment $]$ and articles cited therein. For a general statement as to the scope changes in Revised 9 , see Keith G. Meyer, A Primer on Purchase Money Security Interests Under Revised Article 9 of the Uniform Commercial Code, 50 U. KAN. L. REV. 143, 145-47 (2001) [hereinafter Meyer, Purchase Money Security Interest]. 
Scope or coverage of Article 9 is controlled by UCC section 9-109, which states in part:

(a) [General scope of article.] Except as otherwise provided in subsections (c) and (d), this article applies to:

(1) a transaction, regardless of its form, that creates a security interest in personal property or fixtures by contract;

(2) an agricultural lien;

(3) a sale of accounts, chattel paper, payment intangibles, or promissory notes;

(4) a consignment;

(5) a security interest arising under Section 2-401, 2-505, 2-711(3), or 2A-508(5), as provided in Section 9-110; and

(6) a security interest arising under Section 4-210 or 5-118.

(b) [Security interest in secured obligation.] The application of this article to a security interest in a secured obligation is not affected by the fact that the obligation is itself secured by a transaction or interest to which this article does not apply. ${ }^{14}$

UCC sections 9-109(c) and (d) set forth a number of transactions that are not covered by Article 9. ${ }^{15}$ Some of these include United States statutes, federal treaties, or other state statutes that expressly govern security interests in personal property. Article 9 also does not cover most involuntary liens, landlord liens, and leases of real estate. ${ }^{16}$ A few scope issues of current interest are considered here.

A 2008 Kansas bankruptcy case, In re Wild West World L.L.C., is in effect a scope case. ${ }^{17}$ Here an unpaid seller sold and delivered a good to a buyer. ${ }^{18}$ Seller and buyer expressly agreed that seller's title would not pass to buyer until seller was paid in full. ${ }^{19}$ Buyer, before paying seller,

\footnotetext{
14. U.C.C. § 9-109 (2009).

15. $\S 9-109(\mathrm{c})-(\mathrm{d})$.

16. Id. Agriculture liens are the exception. \$9-102(a)(5); see also supra note 13 and accompanying text.

17. Nos. 07-11620, 07-1193, 2008 WL 4642266 (Bankr. D. Kan. 2008).

18. Id. at $* 2$.

19. Id. at *1
} 
granted creditor a security interest in the good that was purchased on credit. $^{20}$

The issue was whether buyer had sufficient rights in the good to create a security interest in the good. ${ }^{21}$ UCC section 2-401(1) limits any reservation or retention of title in goods shipped or delivered to the retention of a security interest. Section 9-109(a)(5), as set out above, provides that Article 9 applies to a security interest arising under section $2-401 .^{22}$ The court held that seller's voluntary surrender of possession gave buyer sufficient rights in the good to grant a security interest. ${ }^{23}$ Attachment occurred here because an adequate security agreement existed, value was given and the debtor (here buyer) had sufficient rights in the good to create a security interest. ${ }^{24}$ Credit seller must comply with Article 9 to be protected against third parties including buyer's other creditors or a trustee in bankruptcy. While seller may have had a security interest, it did not perfect. Thus, seller loses to a perfected secured creditor. Accordingly, the unpaid credit seller must determine whether any other creditor of buyer has filed a financing statement covering the good. If none exists, seller will file and have priority under the first-to-file rule. ${ }^{25}$ What if a filed financing statement exists? Seller can require cash, seek a subordination from the secured creditor who has

\footnotetext{
20. Id. at **1-2.

21. Id. at $* 2$.

22. Cf. U.C.C. §9-202 (2009) (providing that, in general, title or ownership is irrelevant).

23. In re Wild West World, 2008 WL 4642266 , at *4.

24. § 9-203(a)-(b); cf. § 1-201(b)(35). See generally In re Samuels \& Co., 526 F.2d 1238 (5th Cir. 1976). In this case, debtor's conditional purchase and taking possession of the good established rights for purposes of attachment. Id. at 1241. Since 2001, the so-called "rights" requirement of attachment can be satisfied under section 9-203(b)(2) if the debtor has "the power to transfer rights in the collateral to a secured party." Debtor (buyer) could have obtained this power under UCC section 2-403(1)(b) if buyer purchased the good with a bad check. Buyer has voidable title and the power to transfer good title to a good-faith purchaser. See U.C.C. $\S \S 9-203 \mathrm{cmt}$. 6; 2-403(1)(b); 1 201(29)-(30). See also the definition of good faith in sections 1-201(20), 2-103(1)(b), 9-102(a)(43), and 9-101 cmt. 4.k. See, e.g., In re Samuels, 526 F.2d at 1238; In re McLouth Steel Corp., 22 B.R. 722 (Bankr. E.D. Mich. 1982); In re W. Farmers Ass'n, 6 B.R. 432 (Bankr. W.D. Wash. 1980); Swets Motor Sales, Inc. v. Pruisner, 236 N.W.2d 299 (Iowa 1975).

While apparently the issue of seller's ability to reclaim the goods for nonpayment did not arise in In re Wild West World, remember that unpaid sellers have limited rights of reclamation under 11 U.S.C. § 546(c). Also, UCC section 2-702(2) provides that an unpaid credit seller has the right to reclaim goods upon the discovery of a buyer's insolvency. However, under section 2-702(3) the right to reclaim is not effective against a buyer in the ordinary course or other good-faith purchasers. A secured party is treated as a good-faith purchaser. See $\S \S 1-201(29)-(30) ; 9-203 \mathrm{cmt}$. 6; In re Samuels, 526 F.2d at 1242; cf. U.C.C. § 1-201(b)(35).

25. See U.C.C. $\S 9-322(a)$. But seller must remember that the first-to-file rule is subject to a few exceptions. The biggest being the purchase money security interest super priority under section 9-324.
} 
filed, or determine if the purchase-money exception to the first-to-file rule can be satisfied. ${ }^{26}$

Another scope issue that has been frequently litigated is whether a document entitled a "lease" is in fact a security agreement. ${ }^{27}$ The impact of being a secured transaction rather than a lease is that the rules of Article 9 apply, including the requirement of perfection. These requirements present no difficult obstacles. ${ }^{28}$ It also means that, if a bankruptcy petition is filed and the transaction is determined to be a secured transaction, 11 U.S.C. $\S 365$ of the Bankruptcy Code dealing with executory contracts does not apply.

UCC section 1-203 which is entitled "Lease Distinguished From Security Interest" is the key section. In the 2009 case, In re Gateway Ethanol, L.L.C., the court was confronted with a lease involving an ethanol plant in Chapter 11 bankruptcy. ${ }^{29}$ The basic issue here is whether a document denoted as a lease but containing an option to purchase for a specific price was a true lease or a security agreement

26. See U.C.C. §§ 9-103, 9-322(f), and 9-324. See generally Meyer, Purchase Money Security Interest, supra note 13, at 164-91.

If the collateral is equipment in the hands of the buyer, the seller has a relatively easy task to take priority over a previously filed secured creditor. If the good is inventory in the hands of the buyer, the seller has an impossible challenge to comply with UCC section 9-324(b).

The latter situation can arise in the sale of farm products. Farmer delivers and sells grain to an elevator and receives a bad check from the elevator. A lender has a perfected security interest in the inventory of the elevator, which consists of company-owned grain. Does the elevator have sufficient rights in the collateral so that the lender's security interest will attach to the grain purchased with a bad check? A number of cases relying on UCC section 2-403(1)(b), which gives the elevator voidable title and the power to transfer good title to a good-faith purchaser for value, have held that it does. Because the definition of "purchaser" in UCC sections 1-201(29) and (30) includes a secured party, generally the only question is whether the secured party acted in good faith. See U.C.C. $\S 2-403(1)$.

Farmer probably has a purchase money security interest but to obtain an enforceable security interest under section 9-203, farmer must have an authenticated agreement from the buyer. As a practical matter an elevator will not grant farmer a security interest. Thus, farmer is an unsecured creditor. Even if elevator would grant a security interest, farmer would have to comply with the special requirements of section 9-324(b) which again are impossible to satisfy. See supra note 25 and accompanying text. Under federal law, a qualifying unpaid seller of poultry, livestock, or perishable commodities is given priority over the perfected secured creditor of the buyer. See generally 7 U.S.C. $\S \S 196(b), 197$ (b) (2006).

27. See, e.g., In re Marhoefer Packing Co., 674 F.2d 1139, 1140-41 (7th Cir. 1982) (initial lease term followed by the lessee's option to exercise a number of choices); United States v. Ables, 739 F. Supp. 1439, 1445 (D. Kan. 1990) (no reference to word lease but rent used); In re Cress, 106 B.R. 246, 250 (Bankr. D. Kan. 1989) (true lease under “economic realities" test); In re Int'l Plastics, Inc., 18 B.R. 583, 586 (Bankr. D. Kan. 1982); Excel Auto \& Truck Leasing, L.L.P. v. Alief Indep. Sch. Dist., 249 S.W.3d 46, 51-52 (Tex. App. 2007).

28. See U.C.C. §9-505 (authorizing precautionary filings with no adverse impact on the issue of whether the document called a lease is in fact a lease).

29. 415 B.R. 486, 491 (Bankr. D. Kan. 2009). 
under the UCC. ${ }^{30}$ Under UCC section $1-203,{ }^{31}$ an agreement called a lease can be found to create a security interest in two ways. The first is the so-called bright-line test set forth in UCC section 1-203(b). The party asserting that it is a security interest must establish that consideration is to be paid for the term of the lease, the lease is not subject to termination, and one of the four possibilities set forth in UCC section 1-203(b)(1)-(4) exist. ${ }^{32}$ Second, if the bright-line test is not satisfied, the court must determine from all of the facts whether the economics of the transaction establish a true lease. ${ }^{33}$

The court in In re Gateway Ethanol concluded that the bright-line test is not satisfied. ${ }^{34}$ The question is whether, under UCC section 1201(b)(4), the option purchase price at the end of the lease is nominal. ${ }^{35}$ The court held it was not. ${ }^{36}$ Whether a price is nominal is determined at the time the agreement is signed not at the time the option may be exercised. $^{37}$ The party asserting that the price was nominal has the burden of proof and the court concluded it did not carry its burden of proof. $^{38}$

The court then had to determine whether a true lease existed by examining all the facts of the case. ${ }^{39}$ In effect, the court said the test is

30. Id. at 490

31. U.C.C. § 1-203(b) provides:

A transaction in the form of a lease creates a security interest if the consideration that the lessee is to pay the lessor for the right to possession and use of the goods is an obligation for the term of the lease and is not subject to termination by the lessee, and:

(1) the original term of the lease is equal to or greater than the remaining economic life of the goods;

(2) the lessee is bound to renew the lease for the remaining economic life of the goods or is bound to become the owner of the goods;

(3) the lessee has an option to renew the lease for the remaining economic life of the goods for no additional consideration or for nominal additional consideration upon compliance with the lease agreement; or

(4) the lessee has an option to become the owner of the goods for no additional consideration or for nominal additional consideration upon compliance with the lease agreement.

32. U.C.C. $\S 1-204(b)(1)-(4)$.

33. See U.C.C. § 1-204(a), (c), (e); see also In re Gateway Ethanol, L.L.C., 415 B.R. 486, 503 (Bankr. D. Kan. 2009).

34. Gateway Ethanol, 415 B.R. at 503.

35. See id. at 499-500.

36. Id. at 502 .

37. Id. at 500-01.

38. Id. at 497.

39. Id. at 503 . 
whether the lease provided the lessor a meaningful reversionary interest. ${ }^{40}$ As to facts of the case, the court stated:

The Court, finds the Agreement to be a true lease based upon consideration of: (1) The anticipated useful life of the TO/Boiler; (2) IPE's ability to market the TO/Boiler at the end of the lease term; (3) the amount of the lease payments in relation to the value of the TO/Boiler; (4) whether the TO/Boiler is unique because it was designed for installation in the Gateway plant; (5) whether at the time of the Agreement, the long term operation of the ethanol plan required Gateway's continued possession of the TO/Boiler; and (6) the economic benefit to Gateway and Dougherty from the transaction being structured as a lease rather than a sale.

The court was also confronted with the claim that the "purchaser" should be estopped from asserting that the "lease" was not a true lease. ${ }^{42}$ Two theories are considered under Kansas law: estoppel and quasiestoppel. ${ }^{43}$ The court explained that " $[t]$ he traditional elements of the doctrine of equitable estoppel are: '(1) misrepresentation [of facts] by the party against whom estoppel is asserted; (2) reasonable reliance on that misrepresentation by the party asserting estoppel; and (3) detriment to the party asserting estoppel." 44 Quasi-estoppel is established if it is determined it would be unconscionable to permit a party to benefit by taking a position that is inconsistent with one that the claimant has acquiesced to or from which the claimant accepted a benefit. ${ }^{45}$

\section{B. Scope Issues Regarding Agricultural Credit}

Scope issues involving agricultural credit have arisen in a number of areas. Four particularly interesting ones involve real estate, the flow of payments from an installment land contract or contract for deed, and statutory liens.

Questions relating to real estate have arisen in several situations: seller of land on contract repossesses land with growing crops subject to a perfected security interest of another; mortgagee forecloses real estate mortgage and claims growing crops that are subject to the perfected security interest of another; real estate mortgagee claims an interest in

40. $I d$.

41. Id. at 505 .

42. Id. at 496 .

43. See, e.g., id. at 496-97 (analyzing the theories of quasi-estoppel and equitable estoppel).

44. Id. at 496-97 (quoting In re Isringhausen, 151 B.R. 203, 208 (Bankr. S.D. Ill. 1993)).

45. Id. at 497 . 
growing crops when the farmer-debtor files a bankruptcy petition. PreArticle 9 cases hold that crops unharvested at the time of a real estate foreclosure are part of the real estate and pass with the land at foreclosure. Today, it is clear that a real estate lender wanting an interest in growing crops must comply with Article 9. This is true in all of the situations just set out. ${ }^{46}$

Another scope issue concerns the flow of payments under a contract for deed or an installment land contract. Consider this hypo:

First, on January 2, Owner sells land to Buyer who signs a contract to make monthly payments over 20 years; second, on January 10, Owner borrows money from Bank and the land and the proceeds from the contract are used as collateral. Bank does not file a financing statement; third, on March 1, Owner files bankruptcy petition.

46. UCC section 9-334(i) states "A perfected security interest in crops growing on real property has priority over a conflicting interest of an encumbrancer or owner of the real property if the debtor has an interest of record in or is in possession of the real property." Also, growing crops are specifically included in the definition of goods under Article 9 UCC $\$ 9-102$ (a)(44)(iv). This section defines "goods" as: all things that are movable when a security interest attaches. The term includes (i) fixtures, (ii) standing timber that is to be cut and removed under a conveyance or contract for sale, (iii) the unborn young of animals, (iv) crops grown, growing, or to be grown, even if the crops are produced on trees, vines, or bushes, and (v) manufactured homes. U.C.C. § 9-102(a)(44)

The Kansas Supreme Court in Moritz Implement Co. v. Matthews considered a mortgage foreclosure on land with unsevered crops subjected to a perfected security interest. 959 P.2d 886, 892 (Kan. 1998). It held that Article 9 is the exclusive statutory scheme governing security interests in growing crops. Id. at 890 . Thus, anyone claiming an interest in the crops to satisfy an unpaid debt is subject to Article 9. Moreover, the court held that a perfected security interest in crops remained attached after the redemption period expires in a mortgage foreclosure sale even though the real estate had been transferred as a result of the foreclosure sale. Id. at 892 .

What about growing crops on real estate transferred under a transfer-on-death (TOD) deed and Article 9? In the case of In the Matter of the Estate of Henry M. Roloff, the court held that the TOD deed transferred the growing crops on the real estate when the deed was devoid of any language reserving the growing crops. 143 P.3d 406, 408 (Kan. Ct. App. 2006). It should be noted that crops are treated as personal property in a number of situations other than Article 9. For example, K.S.A. section 59-1206 states: "Annual crops, whether severed or not from the land of the decedent at the time of death, shall be deemed personal assets in the custody of the executor or administrator and shall be inventoried and administered as such." § 59-1206 (2007). The court in Roloff held that this section did not apply because a TOD deed is like a joint tenancy. Roloff, 143 P.3d at 694-95. In both cases no title passes by descent and distribution but rather under a conveyance independent of the estate. Id. at 691. Also, according to Roloff, Article 9 was not relevant because the transferred crops were not subject to a security interest. Id. at 693. Absent anything in the statute to the contrary, if the crops were subject to an enforceable security interest, Article 9 applies. See KaN. STAT. ANN. § 59-3504(b); cf. U.C.C. §§ 2-105, 2-107.

What if the land, at the time of death, had been leased by a person who had a life estate? The doctrine of emblements becomes relevant. Growing crops are treated as personal property when lessor who had a life tenancy in the land dies and both the estate of the lessor and the remainder person claim the crops or their proceeds. See Finley v. McClure, 567 P.2d 851, 854 (Kan. 1977). For a general discussion of crops and the scope of Article 9 that is still relevant to the current version of Article 9, see Keith G. Meyer, A Potpourri of Agricultural U.C.C. Issues: Attachment, Real Estate-Growing Crops and Federalization, 12 HAMLINE L. REV. 741, 754-56 (1989). 
Does Article 9 apply? Yes, Article 9 applies to the flow of payments and bank does not have a perfected security interest because it did not file a financing statement.

Section 9-109(d)(11) provides that Article 9 does not apply to "the creation or transfer of an interest in or lien on real property, including a lease or rents thereunder...." However, the monthly payments are personal property under Article 9. ${ }^{47}$ Under the former version of Article 9, the payments were considered in most states, including Kansas, to be general intangibles which had to be perfected by the filing of a financing statement centrally. ${ }^{48}$ Because Bank in our hypo filed no financing statement, it is an unperfected secured creditor. ${ }^{49}$ Bank is unperfected under the current version of Article 9 also. However, the flow of payments is classified as an account, not a general intangible. Revised Article 9's definition of account is much broader than under former Article 9. ${ }^{50}$ Revised Article 9 defines an account to include the right to payment of a monetary obligation for " "property" that has been sold, leased, licensed, assigned or otherwise disposed of ...." The term property covers both personal as well as real property. ${ }^{51}$ Former Article 9's definition of accounts covered only monetary obligations arising from the sale of goods. "Goods" was defined to include only personal property and fixtures. ${ }^{52}$ Because revised Article 9's definition of account includes the right to payment for "property" sold, the flow of payments under an installment land contract or a contract for a deed is now treated as an account instead of a general intangible. ${ }^{53}$ A security interest in both accounts and general intangibles is perfected by filing centrally. ${ }^{54}$ However, a fatal error will occur if the payments are improperly

47. See, e.g., In re Huntzinger, 268 B.R. 263, 266 (Bankr. D. Kan. 2001). The UCC does not define personal property. Yet, section 9-109(a)(1) provides that Article 9 applies to any "transaction, regardless of form, that creates a security interest in personal property or fixtures ...." Clearly, goods (consumer, equipment, farm products, and inventory) are personal property. See U.C.C. § 9-102(a)(44); see also § 9-102(a)(23), (33), (34)-(35), (48). While not explicitly called personal property, clearly the types of property that can be subject to a security interest such as accounts, chattel paper (tangible), commercial tort judgments, deposit accounts, documents, electronic chattel paper, general intangibles, instruments, investment property, and manufactured homes are personal property. See also BLACK's LAW DictiOnARY 1217 (6th ed. 1990) (defining "personal property" as "everything subject to ownership, not coming under denomination of real estate" and a "right or interest in things personal ...").

48. See, e.g., In re Huntzinger, 268 B.R. at 267.

49. See, e.g., In re Nittolo Land Development Ass'n, Inc., 333 B.R. 237 (Bankr. S.D.N.Y. 2005); In re Huntzinger, 268 B.R. 263.

50. See U.C.C. § 9-102(a)(2)(ii) \& cmt. 5(a).

51. Id.

52. See U.C.C. §§ 9-105(h), -109 (1972) (amended 2001).

53. Compare U.C.C. § 9-102(a)(2)(ii), with § 9-102(a)(42).

54. U.C.C. $\S \S 9-310,-501(a)(2)$. But see U.C.C. $\$ 9-309$ (2) and (3). 
described in the security agreement and financing statement. Types of collateral can be used as descriptions under sections 9-108 and 9-504, but if a drafter today describes this type of collateral as a payment intangible or general intangible, he will be an unsecured creditor as well as unperfected. $^{55}$ This problem can be avoided by simply describing the collateral in lay terms such as "the monthly payments under the contract for deed between buyer and seller dated ...."

Both the former and revised versions of Article 9 cover the sale of accounts. Under the former version, if Owner, in above example, were to have sold the right to receive the flow of payments to Bank instead of using them for collateral, Bank did not have to worry about Article 9. Former Article 9 did not apply to the sale of general intangibles and the flow of payments was considered a general intangible. ${ }^{56}$ However, under Revised Article 9, the flow of payments is an account and the sale of accounts is within the scope of Article 9. ${ }^{57}$ This means Bank-as a buyer of accounts - is considered a secured party and has to file a financing statement to be perfected. ${ }^{58}$

The installment contract transactions raise some other interesting issues. For example, the written contract will typically include all of the provisions necessary to make it an "instrument" under Article 9." A negotiable instrument is a separate, distinct type of collateral and can be perfected by possession or by filing a financing statement. ${ }^{60}$ Moreover, it must be properly described in an authenticated security agreement. The safest course for Bank would be to take possession of the contract to avoid any holder-in-due-course issues. ${ }^{61}$

Similar issues arise when a real estate mortgage is being taken as collateral. Two documents are often involved: a promissory note and a real estate mortgage that secures the note-often called "two-tiered"

\footnotetext{
55. See § 9-203(b)(3)(A) (stating that a security agreement must contain an adequate description for attachment); 9-108 (outlining requirements for a description to be adequate).

56. See U.C.C. $\S \S 9-106,-102$ (1)(b) (1972) (amended 2001).

57. §9-109(a)(3); supra note 50 and accompanying text.

58. See $\S \S 9-109(\mathrm{a})(2),-102(\mathrm{a})(72)(\mathrm{D})$ (stating that secured party includes the buyer of accounts); 9-102(a)(28)(B) (stating that debtor includes the seller of accounts); 1-201(37) (stating that a security interest includes the interest of a buyer of accounts).

59. $\S$ 9-102(a)(47), -104; KAN. STAT. ANN. § 84-9-102(a)(47) (2008).

60. It is important to note that the current UCC defines "promissory note" to mean: "an instrument that evidences a promise to pay a monetary obligation, does not evidence an order to pay, and does not contain an acknowledgment by a bank that the bank has received for deposit a sum of money or funds." U.C.C. § 9-102(a)(65) (2009).

61. See §3-302. Also remember that no authenticated security agreement is needed when the secured party has possession. Clearly, the secured party still must show that the debtor granted a security interest in the contract. See $\S 9-203(b)(3)(B),-201(b)(3)$.
} 
collateral. The promissory note will most times be treated as a negotiable instrument under Article 9. Anybody claiming a security interest in an instrument must comply with Article 9's attachment and perfection rules. Moreover, any priority dispute is controlled by Article 9. ${ }^{62}$ Official comment 7 to UCC section 9-109, dealing with security interests in an obligation secured by land, confirms this conclusion:

Example 1: $\mathrm{O}$ borrows $\$ 10,000$ from $\mathrm{M}$ and secures its repayment obligation, evidenced by a promissory note, by granting to $\mathrm{M}$ a mortgage on O's land. This Article does not apply to the creation of the real-property mortgage. However, if $\mathrm{M}$ sells the promissory note to $\mathrm{X}$ or gives a security interest in the note to secure M's own obligation to $\mathrm{X}$, this Article applies to the security interest thereby created in favor of X. The security interest in the promissory note is covered by this Article even though the note is secured by a real-property mortgage. Also, $X$ 's security interest in the note gives $X$ an attached security interest in the mortgage lien that secures the note and, if the security interest in the note is perfected, the security interest in the mortgage lien likewise is perfected.

Now, returning to the installment land contract hypo, what happens if Buyer under the installment contract and Owner who granted the lender a security interest in the flow of payments both default? ${ }^{64}$ Presumably, real estate law controls who gets the real estate. ${ }^{65}$ Some states have non-uniform Article 9 rules dealing with the recording of installment contracts in the real estate records. ${ }^{66}$

Before concluding the discussion of scope, it is appropriate to consider a non-Article 9 issue related to installment land contracts that is of more interest given the current popularity of owner financing. The issue concerns risk that Buyer under an installment land contract has if Owner, seller, files a bankruptcy petition. Buyer has some risk in Kansas, but the problem can be easily avoided. Consider this hypo:

January 2, 2008, O sells Green Acre to B pursuant to a land installment contract for $\$ 100,000$. B makes a down payment of $\$ 10,000$ and is to pay the remaining $\$ 90,000$ plus interest at $8 \%$ in twelve equal

62. See Provident Bank v. Home Mortgage Corp., 498 F. Supp. 2d 558 (E.D.N.Y. 2007).

63. $\S 9-109 \mathrm{cmt} .7$.

64. Also, consider what happens when the real estate mortgagee defaults on the promissory note secured by the real estate mortgage and the mortgagor who had granted a security interest in the real estate mortgage defaults on its obligations to the lender.

65. See Dale A. Whitman, Transfers by Vendors of Interests in Installment Land Contracts: The Impact of Revised Article 9 on the Uniform Commercial Code, 38 J. REAL PROP., PROBATE \& TRUST 421 (2003).

66. See, e.g., MinN. STAT. § 336.9-619 (2008). 
installments over the next twelve years. B is living on the land. The installment land contract is not recorded.

January 2, 2010, two years after the sale, O files a bankruptcy petition.

The trustee in bankruptcy (TIB) under 11 U.S.C. $\S 544(\mathrm{a})(3)$ is considered to be a bona fide purchaser of real estate of the debtor. If $\mathrm{B}$ does not have legal title, which is probably the case in Kansas, the TIB can claim that he can defeat B's equitable claim to Green Acre as a bona fide purchaser of the real estate from $\mathrm{O}^{67} \mathrm{~B}$ may be protected because B's possession may be sufficient notice to defeat any claim the TIB may have as a bona fide purchaser. ${ }^{68}$ Arguably, this problem can be easily avoided in Kansas by the filing of an affidavit of equitable interest as provided in section 79-3102(d)(5) of the Kansas statute. ${ }^{69}$

The last real estate scope issue concerns federal farm payments for land placed in the Conservation Reserve Program (CRP). Courts have struggled with whether these payments are personal property. ${ }^{70}$ As you will recall, UCC section 9-109(d)(11) excludes from coverage "the creation or transfer of an interest in or lien on real property, including a lease or rents thereunder ....",71

After thoroughly considering the cases and issues, a Kansas Bankruptcy Court in In re Isenbart, held that CRP payments are personal property rather than rent of real estate. ${ }^{72}$ They are in the nature of contract rights, general intangibles, or accounts under Former Article 9. ${ }^{73}$ This decision was decided when Former Article 9 was in effect. Clearly, Revised Article 9 applies to any transaction creating a security interest in personal property, which the CRP payments are under this decision. The question is, how are the CRP payments classified under Revised Article 9? Comment 5 to Revised Article 9 section 102 provides:

This Article does not contain a defined term that encompasses specifically rights to payment or performance under the many and

\footnotetext{
67. 11 U.S.C. § 544(a)(3).

68. See McCannon v. Marston, 679 F.2d 13, 17 (3d Cir. 1982) (holding possession by the buyer prevented the TIB from winning under $\S 544(\mathrm{a})(3))$.

69. See Kan. Stat. AnN. § 79-3102(d)(5). The statute provides in part: "No registration fee whatsoever shall be paid, collected or required for or on: . . . any mortgage or other instrument given in the form of an affidavit of equitable interest solely for the purpose of providing notification by the purchaser of real property of the purchaser's interest therein ...."

70. See, e.g., In re Isenbart, 255 B.R. 62 (Bankr. D. Kan. 2000).

71. U.C.C. § 9-109(d)(11) (2001).

72. 255 B.R. at 67.

73. Id.
} 
varied government entitlement programs. Depending on the nature of a right under a program, it could be an account, a payment intangible, a general intangible other than a payment intangible, or another type of collateral. The right also might be proceeds of collateral (e.g. crops). ${ }^{74}$

In my opinion, the court reached the correct result. CRP payments are like virtually every other farm program payment that deals with payments based upon the farmer's land. The government is not the lessee but is a party to a contract under which the farmer promises to do certain things and the government in return promises to pay a certain amount. It is not a conveyance of land. The government has no right to possess or farm the land. If CRP payments are considered to be personal property, the classification of a government payment becomes important and it is in my opinion a general intangible virtually like every other farm program payment. If the farm program payment is classified as a payment intangible, both the sale of the farmer's right to receive program payments, as well as the transaction creating a security interest in the payment intangible to secure a loan, are covered by Revised Article 9. ${ }^{75}$ "Payment intangible" is defined to mean: "a general intangible under which the account debtor's [federal government's] principal obligation is a monetary obligation.,"76

\section{Miscellaneous Scope Issues}

Two other scope issues that will not be discussed in any detail here involve current Kansas issues. One relates to statutory agricultural liens and the other to extracted oil and gas and their proceeds.

One of the most significant revisions of Article 9 in 2001 concerned nonpossessory liens in agricultural products. For the first time, a nonpossessory statutory lien defined as an "agriculture lien" 77 is subject to Article 9's perfection, priority, and enforcement rules. Every state except Kansas included this coverage in some form. The Kansas legislature excluded from the coverage of Article 9 nonpossessory agricultural liens in farm products created by the statutory liens listed in

\footnotetext{
74. U.C.C. § 9-102 cmt. 5(i) (2001).

75. §9-109(a)(1), (3) (2009).

76. §9-102(a)(61). "General intangible" is defined in section 9-102(a)(42) as "any personal property, including things in action, other than accounts, chattel paper, commercial tort claims, deposit accounts, documents, goods, instruments, investment property, letter-of-credit rights, letters of credit, money, and oil, gas, or other minerals before extraction. The term includes payment intangibles and software." $\$ 9-102(a)(42)$.

77. $\S 9-102(a)(5)$.
} 
sections 84-9-102(a)(76) and 9-102(a)(5) of the Kansas Statutes. ${ }^{78}$ Creditors thinking about, or taking a security interest in farm products in Kansas have a variety of statutory liens to consider. These liens have no uniformity as to creation, perfection, priority, and enforcement. This uncertainty also applies to the purchasers of farm products subject to a statutory lien. I have discussed these issues extensively in a prior article. $^{79}$

Another issue that must be mentioned briefly concerns extracted oil and gas. Before extraction, oil and gas are treated as real property. ${ }^{80}$ Article 9 now covers "as-extracted collateral." ${ }^{\prime \prime 1}$ The term "as-extracted collateral" is defined in UCC section 9-102(a)(6) and refers to oil, gas, or other minerals that are subject to a security interest before extraction from the ground and attaches to the minerals as extracted. ${ }^{82}$ Upon extraction, minerals become personal property. ${ }^{83}$

Three recent bankruptcy court decisions dealing with conflicts between secured creditors and unpaid producers of oil that were given special protections via non-uniform amendments to Article 9 are significant. ${ }^{84}$ Non-uniform amendments to the perfection rules did not protect the unpaid producers. ${ }^{85}$

\section{PERFECTION}

\section{A. In General}

In general, attachment makes the security interest enforceable against the debtor and it allows the secured party to pursue its remedies on default as articulated in Part 6 of Article 9, whether or not the security

78. See KAN. STAT. ANN. § 84-9-201(b)(2) (purporting that Article 9 is subject to state statutes that create a different rule "including, but not limited to, K.S.A. sections 2-1319, 2-2608, 2-3007, 34-239, 47-836, 58-201, 58-203, 58-204, 58-207, 58-218, 58-220, 58-221, 58-241, 58-242, 58-2524, $58-2525,58-2526,58-2527,58-2528$ and 84-7-209..."). Most of these sections deal with agricultural liens.

79. Meyer, Unique Treatment, supra note 13.

80. U.C.C. $§ 9-102 \mathrm{cmt}$. 4(c) (2009).

81. See id.

82. See id.

83. See id.

84. See generally In re SemCrude, L.P., 407 B.R. 140 (Bankr. D. Del. 2009) (giving protection through Oklahoma special statutes, one being a Lien Act); In re SemCrude, L.P., 407 B.R. 112 (Bankr. D. Del. 2009) (allowing for Texas automatic perfection for unpaid producers); In re SemCrude, L.P., 407 B.R. 82, 2009 (Bankr. D. Del. 2009) (limiting a Kansas purchase money security interest by Kansas statutory law).

85. See generally sources cited supra note 84 . 
interest is perfected. ${ }^{86}$ A security interest cannot be perfected until it has attached and all steps required for perfection are taken. ${ }^{87}$ Perfection is required to protect the security interest against third parties, such as purchasers of collateral subject to a security interest, other creditors, and the trustee in bankruptcy. Remember that perfection does not give protection against the entire world. ${ }^{88}$

\section{B. Certificate of Title Collateral}

Unless a specific section provides otherwise, the normal way to perfect under Article 9 is to file a proper financing statement centrally. ${ }^{89}$ Security interests in motor vehicles (also boats in some states) that are subject to certificate of title statutes must be perfected by notation on the

86. See U.C.C. §§ 9-201, -203(a), -601(a)

87. Perfection is designed to give public notice of a security interest. See U.C.C. §§ 9-308, 501. Section 9-308 defines perfection:

(a) [Perfection of security interest.] Except as otherwise provided in this section and Section 9-309, a security interest is perfected if it has attached and all of the applicable requirements for perfection in Sections 9-310 through 9-316 have been satisfied. A security interest is perfected when it attaches if the applicable requirements are satisfied before the security interest attaches.

Attachment is defined and controlled in general by UCC section 9-203. In general, value must be given, the debtor must have rights in the collateral or the power to transfer rights in the collateral to a secured party, and an appropriate agreement creating a security interest must be executed. Sections 9-203(b)(1) and 1-201(44) deal with value. For a thorough discussion of attachment requirements see JAMES J. WHITE \& ROBERT S. SUMMERS, UNIFORM COMMERCIAL CODE 1185-93 (6th ed. 2010); Keith G. Meyer, Current Issues and Agricultural Credit, 10 DraKE J. AGRIC. L. 105, 135-63 (2005).

In general, depending upon the type of collateral, perfection can occur in seven possible ways: (1) by filing, section 9-310; (2) through possession by secured party, section 9-313; (3) automatically upon attachment, section 9-309; (4) possessing certificate of title, sections 9-310(b), 9-311; (5) through control, sections 9-104 and 9-314; (6) temporarily, section 9-312(d), (e); and (7) through an assignment of a perfected security interest under section 9-310(b).

88. For example, UCC section 9-320(a) allows the buyer in the ordinary course to cut off a perfected security interest in inventory. A valid perfected security interest in after-acquired inventory, livestock, and software or equipment or other goods that are not inventory or livestock lose to a later perfected qualifying purchase money security interest (PMSI) in inventory, livestock, software or equipment, or other goods that are not inventory or livestock. Put another way, the "dragnet clause" that covers not only collateral for an immediate loan, but also loans made in the past or the future will give the lender priority dating from the time the financing statement is filed unless a qualifying subsequent PMSI holder surfaces. See U.C.C. § 9-324 (2009). Specifically, see UCC sections 9-322 cmt. 5 and 9-323 cmt. 3 dealing with future advances. See generally Meyer, Purchase Money Security Interest, supra at note 13.

A recent case upholding a "dragnet clause" in a non-agricultural setting is Pride Hyundai, Inc. v. Chrysler Financial Co., 369 F.3d 603 (1st Cir. 2004). However, perfection which occurs more than ten days after the creation of the security interest and within ninety days of bankruptcy will probably be set aside as a preferential transfer under $\S 547(\mathrm{~b})$ of the Bankruptcy Code unless a purchase money security interest is involved. See 11 U.S.C. § 547(b)(4), (c)(3); U.C.C. § 9-103.

89. See generally U.C.C. $\S \S 9-310,9-501$. 
title except for those that are held as inventory by a person in the business of selling goods of that kind.$^{90}$ If a vehicle or boat is not subject to a certificate of title statute, other perfection rules apply. For example, if the collateral is equipment not subject to a certificate statute, the normal filing rules apply. ${ }^{91}$ If the collateral is a consumer good and a purchase money security interest (PMSI) is involved, the security interest is automatically perfected. ${ }^{92}$ On the other hand, the automatic perfection rule does not apply when the vehicle is subject to a certificate of title statute- even if the debtor is a consumer and the financing enabled the debtor to acquire the vehicle. ${ }^{93}$

Thus, the crucial question is whether the vehicle or boat is subject to a certificate of title statute. Normally, the question is whether the vehicle or boat must be registered and have a license tag issued. ${ }^{94}$ In general, nonhighway vehicles are not covered by certificate of title statutes. In Missouri, an Arctic Cat snowmobile is not a "motor vehicle" subject to the Missouri certificate of title statute. ${ }^{95}$ Thus, a creditor who establishes a PMSI in consumer goods is automatically perfected upon attachment and does not have to deal with a certificate a title. ${ }^{96}$ This issue also arose in an Ohio bankruptcy case. In In re Palmer, debtor, a dog kennel owner, signed a purchase and loan agreement in his individual name and stated that the compact utility tractor and front loader would be used for his personal use. ${ }^{97}$ The tractor was not subject to the Ohio certificate of title statute. The issue was whether the tractor was a consumer good and subject to the automatic perfection rule. The court noted that the burden of inquiry is on the creditor to determine the intended use of the collateral. ${ }^{98}$ The court held that the tractor seller was justified in relying on debtor's representations that the tractor was for personal use, making it a consumer good under Article 9. ${ }^{99}$ The seller had a PMSI in consumer goods and therefore could rely upon the automatic perfection rule for PMSI's in consumer goods and did not have to file a financing statement

90. Id. $\S \S 9-310(\mathrm{~b})(3), 9-311 ; c f .9-309$ (1) (stating that consumer goods subject to a treaty or statute do not perfect on attachment).

91. See § 9-310(a).

92. §9-309(1).

93. Id.

94. See, e.g., KAN. STAT. ANN. §§ 8-127 to 28 (2008).

95. In re Lance, 59 U.C.C. Rep. Serv. $2 \mathrm{~d}$ (CBC) 632 (Bankr. W.D. Mo. 2006).

96. Id.

97. 365 B.R. 816,817 (Bankr. S.D. Ohio 2007)

98. Id. at 822 ("When a creditor fails to make an inquiry and instead assumes what the use of the product will be, it does so at its own risk.").

99. U.C.C. § 9-102(a)(23) (consumer goods are goods "used or bought for use primarily for personal, family, or household purposes"). 
to be perfected. ${ }^{100}$ Again, note that the tractors were not subject to a certificate of title statute.

Kansas law on the perfection of vehicles is worth a closer examination. Basically, vehicles are divided into two classes: vehicles that must be registered-so-called highway vehicles - and those that need not be registered-so-called nonhighway vehicles. ${ }^{101}$ The general rule has been that registered vehicles are subject to the certificate of title statute and nonregistered vehicles are not. ${ }^{102}$ The rules dealing with certificate of titles and security interests have changed in a variety of ways in the last six years. Three of these are considered here. First, on January 1, 2003, the legislature altered the rules to recognize electronic certificate of titles. ${ }^{103}$ Then, on July 1,2007 , the rules were changed by expressly providing that perfection of a security interest in a vehicle subject to the certificate of title statute occurred "upon the mailing or delivery of the notice of security interest and tender of the required fee." 104 Last, on July 1, 2009, the term "farm tractors" was removed from the list of collateral subject to the certificate of title statute referred to in K.S.A. section 84-9-311. ${ }^{105}$

Each of these changes will be considered. The 2007 change dealing with perfection by mailing of a notice of a security interest was considered in the case of In re Hicks. ${ }^{106}$ In this case, Credit Union had obtained a PMSI in a Ford SUV and had Debtor sign a properly completed "Notice of Security Interest" (NOSI) that was mailed with the appropriate fee to the Kansas Department of Revenue (KDOR). KDOR received the NOSI, but the NOSI was not entered into its computer. When Debtor filed his application for title, no mention was made of Credit Union's security interest in the vehicle. KDOR issued a certificate of title with no liens noted on it.

Debtor filed a Chapter 7 and the trustee attacked Credit Union's claim to the Ford as being unperfected because its lien was not noted on the certificate as required by the Kansas certificate of title statute, K.S.A.

\footnotetext{
100. $\$ 9-309(1)$.

101. See KAN. STAT. ANN. § 8-127 (2009) (requiring registration of vehicles "intended to be operated upon any highway in this state").

102. See $\S 8-135(\mathrm{c}),(\mathrm{c})(5)$.

103. See $\S 8-135 d(a),(b)$. Changes have been made in a variety of areas. For example, several statutes were changed concerning "Micro utility truck." See, e.g., §§ 8-2401, -126, -128, -197, 1486, and -2118. Also changes have occurred as to titled manufactured homes, all-terrain vehicles (ATV), work site utility vehicles, and "Micro utility trucks." These have been made subject to the electronic filing procedures when perfecting a security interest.

104. KAN. StAT. ANN. § 84-9-311.

105. Id.

106. 491 F.3d 1136 (10th Cir. 2007).
} 
section 8-135(c). The bankruptcy court agreed but it was reversed by the federal district court. The district court held that under the statute the lender was perfected when the proper NOSI was deposited in the mail notwithstanding the motor vehicle division's failure to get the lien noted on the title. In effect, the district court held that a creditor is perfected by a proper notation on the title or the mailing of a proper NOSI. The Court of Appeals for the Tenth Circuit reversed the district court and held that under Kansas law the filing of a NOSI lost its effectiveness once KDOR issued a certificate of title showing no lien.

As noted above, the 2007 Kansas Legislature in an apparent response to In re Hicks, amended Kansas's version of UCC section 9-311(a) dealing with perfection and vehicles subject to a certificate of title by providing:

Such security interest shall be deemed perfected upon the mailing or delivery of the notice of security interest and tender of the required fee to the appropriate state agency as prescribed by subsection (c)(5) of K.S.A. 8-135 and subsection (g) of $58-4204$, and amendment (i) of 584204 , and amendments thereto $\ldots .$.

Some interesting questions still remain unanswered. What happens when a NOSI is received by the department but no lien is noted on an issued certificate of title and the vehicle is sold or the vehicle is used as collateral for a new loan? Does the purchaser take free of original creditor's security interest? Does the first creditor have priority over a second creditor who took a security interest in a vehicle that had a clean certificate of title? Is the purchaser or the second creditor to be treated in the same manner as the trustee in bankruptcy who is not a reliance creditor? These issues are made more complex in view of the fact that, since January 1, 2003, no paper certificate of title exists for a vehicle subject to a security interest (lien). ${ }^{108}$ Rather, the title to the vehicle is maintained electronically by the Department of Revenue's Division of Motor Vehicles. It is my understanding that titles without liens are still issued as paper certificates, and paper certificates will be issued once any lien is released. ${ }^{109}$ Notwithstanding, the new electronic rules and the fact

107. Kan. Stat. ANN. § 84-9-311.

108. Beginning in 2003, the Kansas E-lien program enabled financiers to file a "Notice of Security Interest" (NOSI) electronically. For financiers to be able to make electronic filings, they must be registered with the Kansas Division of Motor Vehicles. See Welcome to the Kansas Motor Vehicle Electronic Lien Filing and Release System, http://www.ksrevenue.org/Kselien.htm (last visited Mar. 12, 2010). See also Forms and Publications: Motor Vehicles, http://www.ksrevenue.org /forms-dmv.htm (last visited Mar. 12, 2010).

109. See KAn. StAT. AnN. § 8-153(d) (2009). The NOSI is Kansas Department of Revenue 
that Kansas's current version of UCC section 9-311(a)(2) provides that perfection of a security interest in a vehicle subject to the certificate of title statute occurred "upon the mailing or delivery of the notice of security interest and tender of the required fee," 110 nothing is said about priority rules. Obviously, section 9-311 deals with perfection and unless otherwise provided, the normal priority rules of Article 9 apply when more than one party claims the same collateral.

While the UCC filing rules are not directly applicable to certificate of title perfection issues, section 9-517 (indexing errors), and section 9516(d) (creditors who rely on an erroneous filing) should be considered by analogy. Section 9-517, dealing with filing office errors when a properly completed financing statement is submitted, states: "The failure of the filing office to index a record correctly does not affect the effectiveness of the filed record." This section applies to the proper submission of the record with fee to the filing office. Interestingly, no mention is made of certificates of title. Compare this with the language of UCC section 9-311(b), which again is a perfection rule not a priority rule. It is also interesting to compare section 9-516(d), which is a perfection rule, but contains a priority rule within it. Section 9-516(d) deals with a situation where the filing officer inappropriately rejects a proper financing statement. Notwithstanding the fact that no filing exists, the creditor is considered perfected except as to "purchasers" of the collateral who give value in reasonable reliance upon absence of the filing. ${ }^{111}$ The term "purchase" applies only to liens created voluntarily,

form TR-730. Notice of Security Interest, http://www.ksrevenue.org/pdf/forms/tr730.pdf (last visited Mar. 12, 2010). When a bank has loaned the money for the purchase or the seller is providing the financing of the purchase of a new or used car, the debtor is required to apply for the title. The creditor, to be perfected before the security interest is noted on the title, must file a NOSI within thirty days after the vehicle is purchased. The creditor can mail or deliver the properly completed NOSI. Upon the mailing or delivering the properly completed NOSI the creditor is perfected. KAN. STAT. ANN. § 84-9-311.

110. U.C.C. $\S 9-311($ a)(2).

111. See $\S \S 1-201(29)$, (30) (defining "purchaser" as one who voluntarily takes a security interest); 9-517. This issue can arise under section 9-517 in several different ways. For example, when a secured creditor submits a properly completed financing statement with the appropriate fee to the appropriate filing office but the financing statement is not filed or it is terminated without authority and without notification to the secured party. Similarly, if secured party \#1 properly submits a financing statement and the filing office files the financing statement under the wrong name, secured party \#1 is perfected. If secured party \#2, after searching the records and finding no financing statement, loans money to debtor and obtains a perfected security interest, secured party \#2 will lose to secured party \#1. Secured party \#1's financing statement was mis-indexed but secured party \#1 is considered to have filed first unless secured party \#2 can fall under a special exception to the first to file rule.

Is the filing office liable for mistakes? Under former Article 9 many states enacted nonuniform provisions to insulate filing offices from liability except for willful conduct. At least one stateKansas-has carried this forward in revised Article 9. See KAn. STAT. AnN. § 84-9-523(f) (2009). 
which means that the TIB as a lien creditor under 11 U.S.C. $\S 544(a)(1)$ will not be able to use this section to defeat the creditor who is not of record. Also, note that UCC section 9-520(c) applies a similar rule when the filing officer improperly accepts a financing statement that contains incorrect information that is required by UCC section 9-516(b)(5) such as the mailing address of the debtor or an inappropriate designation of business status. ${ }^{112}$

At least one court has concluded that certificate of title perfection issues are not subject to the same perfection standards as set forth in Article 9. In In re Laursen, the court held that Article 9 rules regarding the debtor's name do not apply to certificate of title errors in the debtor's name. ${ }^{113}$ Under Idaho law, Creditor was perfected even though there was a one character error in Debtor's name on the certificate of title"Whitney, but it is listed as "Whitnet.",114 Debtor's name is not as crucial to notice system for vehicles as it is for the notice system in the UCC. The vehicle identification number is paramount. ${ }^{115}$

Other states that had similar protections under former Article 9 included Iowa, Kentucky, Minnesota, Missouri, Nebraska, North Dakota, Oklahoma, and Wisconsin. See Borg-Warner Acceptance Corp. v. Dep’t of State, 426 N.W.2d 717 (Mich. Ct. App. 1988), rev'd, 444 N.W.2d 786 (Mich. 1989).

112. U.C.C. $\$ 9-520(\mathrm{c})$.

113. 391 B.R. 47 (Bankr. D. Idaho 2008).

114. Id. at 49 .

115. Federal tax liens present another area where Article 9 rules dealing with the debtor's name and the minor error rule have been held inapplicable. According to the Court of Appeals for the Sixth Circuit in In re Spearing Tool and Mfg. Co., federal tax liens were not subject to the exact match standard for searches under Article 9. 412 F.3d 653 (6th Cir. 2005). Spearing Tool apparently means that someone searching for Article 9 financing statements and I.R.S. liens will have to search more than just the legal name of the debtor. It is interesting to speculate whether filing offices will develop two search engines. Also, if the search engine exists for nonlegal names, it would seem that this search will turn up incorrect legal names.

UCC section 9-506(c) deals with whether the minor error rule can apply to a filed financing statement containing an incorrect debtor name. This section provides that a financing statement substantially complying with the requirements of the 9-500 sections is effective even if it has minor errors or omissions unless those errors or omissions make the financing statement seriously misleading. A financing statement containing an incorrect debtor's name is not seriously misleading under UCC section 9-506(c) if a search of the records of the filing office under the debtor's correct name, using the filing office's standard search logic (if any) discloses the financing statement filed under the incorrect name. The key questions are: (1) what is the debtor's correct name and (2) what is the official search logic of the filing office? Many states' filing offices are using an exact match search logic. This means that a search under the correct name of an individual using the exact match logic will only produce a financing statement indexed under the identical name of the debtor. In effect, there is no minor error rule when an exact match logic is used. If the correct name of the debtor is the debtor's legal name, financing statements filed under a nonlegal name are misleading because an exact match search would not find them. Some states, like Kansas and Missouri, have promulgated regulations that define the search logic to be used. See, e.g., Kan. Admin. REgS. § 7$17-22(a)(1)-(8)$.

For recent cases dealing with the exact match search logic, see generally In re Borden, 353 B.R. 886 (Bankr. D. Neb. 2006) (filed financing statement under "Mike Borden" when debtor's name was Michael Borden was insufficient); In re Tyringham Holdings, Inc., 354 B.R. 363 (Bankr. E.D. Va. 
Another issue related to UCC section 8-135(c)(5) is that perfection by mailing a proper NOSI only applies to PMSIs and not to nonPMSIs. ${ }^{116}$ The section's language on its face is limited to PMSIs. Kansas's analogue, K.S.A. section 8-135(d)(5), provides in relevant part:

[U]pon sale and delivery to the purchaser of every vehicle subject to a purchase money security interest as provided in article 9 of chapter 84 of the Kansas Statutes Annotated, and amendments thereto, the dealer or secured party may complete a notice of security interest and when so completed, the purchaser shall execute the notice, in a form prescribed by the division, describing the vehicle and showing the name and address of the secured party and of the debtor and other information the division requires.

When a non-PMSI is involved, the vehicle will already be owned by the debtor and either a paper or electronic title will exist. While it is beyond the scope of this Article to deal with this issue in any detail, the secured party must get its lien noted on an existing title.

Two types of title exist: a paper title or an electronic title. If a paper title exists and the debtor has possession of the title, the secured party should note its lien on the existing title and deliver it to the appropriate county treasurer along with an application for Duplicate, Secured, or Reissued title found in form TR-720B. ${ }^{118}$ The debtor will also have to deal with filing a Duplicate Title Certification found in form TR-720B. When an electronic title is involved, the secured creditor must obtain from the debtor the current title and registration receipt (Form TR-200) and file it with an application for Duplicate, Secured or Reissued title form TR -720B.

In short, any creditor, lender, or seller who wants to perfect a security interest in any vehicle subject to the certificate of title statute and not held as inventory must deal with the Kansas E-Lien program that went into effect in 2003 and was enhanced in 2009. ${ }^{119}$ It should also be noted that electronic filing procedures apply to titled manufactured homes, all-terrain vehicles, work site utility vehicles, and micro utility trucks.

\footnotetext{
2006) (financing statement that did not contain the same corporate name for the debtor as that on the public record for the State of Virginia, in that it omitted the "Inc." from the end of debtor's name, was seriously misleading).

116. U.C.C. § 9-103(a) (defining PMSI).

117. KAn. Stat. ANN. § 8-135(d)(5) (2009) (emphasis added)

118. For the appropriate forms see supra note 108 .

119. The key agency here is the Kansas Division of Motor Vehicles, Titles and Registration Bureau. See supra note 108.
} 


\section{PERfected SECured CREditors Versus Buyers of NON-FARM PRODUCTS}

A priority conflict arises when a debtor sells to a buyer a good subject to a security interest. ${ }^{120}$ The question is whether the secured creditor can replevin the good or sue the buyer for conversion. Some of the various factual situations where this issue arises will be considered here.

The general rule is found in UCC section 9-315(a)(1). It provides that, except as otherwise provided by Article 9 or section 2-403(2), a security interest continues in collateral notwithstanding sale or exchange unless the secured party authorized the disposition free of the security interest or agriculture lien. ${ }^{121}$ In short, unless the buyer can point to a rule that protects the buyer, the buyer buys the good subject to the security interest. One of the exceptions to the general rule is found in UCC section 9-320 that provides in part:

(a) Except as otherwise provided in subsection (e), a buyer in ordinary course of business, other than a person buying farm products from a person engaged in farming operations, takes free of a security interest created by the buyer's seller, even if the security interest is perfected and the buyer knows of its existence. ${ }^{122}$

Another exception to the general rule is found in UCC section 9317(b) that provides: "[A] buyer, other than a secured party, of ... goods ... takes free of a security interest or agriculture lien if the buyer gives value and receives delivery of the collateral without knowledge of the security interest or agriculture lien and before perfected."123

Consider three hypos that are based upon these basic facts: On January 1 Bank loans $\$ 200,000$ to Farmer (F) who grants Bank an enforceable security interest in all farm equipment including but not limited to a JD combine \#1, a JD tractor, and a 350 Ford pickup truck. Bank files a proper financing statement in the correct office describing the collateral as "all equipment." Bank does not get its security interest noted on the Ford pickup's certificate of title. The pickup is used only for farm business but is driven on the highway.

\footnotetext{
120. U.C.C. § 9-102(a)(44) (2001) (defining "goods")

121. $\S 9-315(\mathrm{a})(1)$.

122. §9-320(a)(1).

123. $§ 9-317(b)$.
} 
Hypo \#1: Sale of the combine \#1 to F2:

On October 1, Farmer (F) sells combine \#1 to Farmer 2 (F2) who pays $\mathrm{F}$, takes delivery and does not know about Bank's security interest. Bank does not know about the sale. On November 1, F defaults on his obligations to Bank. On December 1, Bank learns F2 has combine \#1 and files an action to repossess combine \#1. Who wins between Bank and F2?

Bank should win. The security interest is not cut off by F's sale to F2. Bank has a perfected security in the combine which under Article 9 is equipment. ${ }^{124}$ No exceptions exist to protect $\mathrm{F} 2$ from the basic rule of section 9-315(a)(1) that the security interest follows the collateral notwithstanding sale. ${ }^{125}$ First, Bank did not know about the sale and did not authorize it. Second, none of the so-called "buyer rules" found in section 9-320(a) or section 9-317(b) protect F2. Section 9-320(a) does not help F2 because F2 is not a buyer in the ordinary course of business. ${ }^{126}$ The definition of a "buyer in ordinary course of business" in UCC section 1-201(9) requires that the buyer buy from someone in the business of selling goods of that kind. ${ }^{127} \mathrm{~F} 1$ is not in the business of selling combines. ${ }^{128}$ Section 9-317(b) does not apply because Bank had a perfected security interest before F2 bought the combine. ${ }^{129}$ The only possibility of Bank being unperfected is if combine \# 1 was subject to the certificate-of-title rules requiring notation of the security interest on the

124. U.C.C. § 9-102(a)(33) “"Equipment' means goods other than inventory, farm products, or consumer goods."). "Goods" are defined in section 9-102(a)(44). "Consumer goods" are defined in section 9-102(a)(23). "Inventory" is defined in section 9-102(a)(48). Farm products are defined in section 9-102(a)(34-35). Equipment is perfected by filing. § 9-310(a). See also U.C.C. § 9-102 cmt. 4a (explaining the use of "goods").

125. See U.C.C. § 9-315(a)(1).

126. $\S 9-320(\mathrm{~b})$ is another exception to the general rule that a security interest follows the collateral notwithstanding sale but it only applies to consumer goods in the hands of the seller and the buyer. This exception obviously does not apply to this first hypo because the combine is equipment in the hands of the seller, $\mathrm{F}$.

127. §1-201(b)(9) (defining a "buyer in the ordinary course").

128. The Kansas case of Ronald v. Odette Family Ltd. P'ship v. Ageo Fin., 129 P.3d 95 (Kan. Ct. App. 2005), involved facts similar to this hypo. The court held that a buyer who purchased a tractor and loader subject to a perfected security interest from a farmer could not maintain a conversion action against the secured creditor who repossessed the tractor. Id. at 102. The seller was a farmer, not a dealer of tractors and loaders, and the buyer did not qualify as a buyer in the ordinary course. $I d$. at 101 . The court indicated that the buyer could have concluded that a security interest was involved. Id. Remember, however, that mere knowledge of a security interest is not enough to prevent a buyer from being a buyer in the ordinary course. See U.C.C. § 9-320 cmt. 3.

129. See U.C.C. §9-317(b). 
certificate of title. In most states, including Kansas, combines are not subject to certificate-of-title rules. ${ }^{130}$

The upshot is that Bank can get the combine from F2, who has lost both the combine and the money paid to F. F2 has a cause of action under UCC section 2-312 for breach of warranty of title ${ }^{131}$ against its seller (F), but $F$ is probably judgment-proof. The risk of loss is placed on F2. Buyers buying from a person not engaged in the business of selling the particular good run the risk that the good is subject to a perfected security interest and that seller will not pay off the debt after the sale. So-called "big ticket" items should raise an automatic red flag that they may be collateral for the purchase price. Certainly, used combines are very expensive, easily $\$ 30,000$ plus. Moreover, most farmers finance "big ticket" purchases and therefore are aware of this possibility. Assuming that the secured party has acted reasonably and done everything a prudent secured creditor would do, the risk of loss is placed on the farmer-buyer.

A legitimate issue is whether farm equipment like tractors and combines should be made subject to the certificate-of-title statutes. Arguably, such a rule would make it much easier for a buyer to determine if a combine or tractor was subject to a security interest. Does it make sense to change the rule? Some of the considerations include: (1) What are the costs and the benefits of changing the rule; (2) Is there a significant problem that would be solved by notation on the title; (3) How much more would it cost the system and the players if notation on the certificate of title, rather than filing a financing statement, became the rule; and (4) Would the process work better than requiring the farmerbuyer to search the filed records? In the past, it has been relatively easy for the buyers of used vehicles subject to certificate-of-title laws to determine if a lien existed. To be perfected, the security interest had to be noted on the certificate of title. Thus, prospective buyers simply asked to see a paper certificate.

In Kansas, the advent of electronic titles for vehicles subject to the certificate-of-title rule complicated the sale process both for someone buying a vehicle and a lender who is being asked to finance the purchase of a used vehicle. It is beyond the scope of this article to cover all of the details, but a few general observations are in order. Cash sales of cars with paper titles with no liens are apparently the same today as before

130. See supra Part III.B

131. See U.C.C. § 2-312. 
January 1, 2003. Non-PMSI loans where a paper title exists without any liens noted on it are also apparently treated the same as before $2003 .^{132}$

Titles subject to liens have different rules. If a paper certificate of title exists and has a lien noted on it, buyer and seller must execute a revenue Electronic Title Sales Agreement Form (TR-39a), which buyer delivers to the county treasurer. This starts the process of getting a new title issued. Since 2003, no paper title has been issued when a vehicle is subject to a lien until the lien has been paid and released. ${ }^{133}$ Any purchaser of, or financier of a purchaser of, a vehicle subject to a certificate of title must deal with Kansas's E-lien program. ${ }^{134}$

Hypo \#2: F sells the tractor to F2:

On October 1, F sells the tractor to F2, who pays F, takes delivery, and does not know about Bank's security interest. Bank does not know about the sale. On November 1, F defaults on his obligations to Bank. On December 1, Bank learns F2 has tractor and files an action to repossess tractor. Who wins between Bank and F2?

Bank should win unless the tractor is subject to the relevant state's certificate-of-title law requiring Bank's security interest to be noted on the certificate of title. Assuming the tractor is not subject to a certificateof-title statute, which is the case in most states, ${ }^{135}$ the analysis is the same as in Hypo \#1. As noted above, if a vehicle is subject to a certificate-oftitle statute, perfection rules other than filing apply. ${ }^{136}$

Hypo \#3: F trades Combine \#1 to Dealer:

On October 1, unbeknownst to Bank, F trades combine \#1 in to Dealer as part payment of the purchase price for a new combine. On October 5, Dealer sells combine \#1 to F2. Bank does not know about the sale. On November 1, F defaults on his obligations to Bank. On December

132. See supra Part III.B.

133. See Kan. Stat. AnN. § 8-135d(a) (Supp. 2008).

134. See supra Part III.B.

135. See generally Aaron K. Johnstun \& Stephen J. Ware, Farm Tractors in Kansas: How to Perfect a Security Interest, 57 U. KAN. L. REV. 409 (2009) (discussing Kansas's system of subjecting tractors to the certificate-of-title rules rather than ordinary perfection rules). But see U.C.C. §§ 9310(b)(3), -311(a)(2), -311(b) (setting out perfection rules for property subject to certificate-of-title statutes). While most participants in the process believed that tractors were treated as equipment and not subject to the certificate-of-title laws, the 2009 Kansas legislature attempted to make this a clear rule by changing section 84-9-311 of the Kansas Statutes. See 2009 Kan. Sess. Laws 631 (removing the word "tractor").

136. See U.C.C. $\S \S 9-310(b)(3),-311$. The main Kansas certificate-of-title statute is K.S.A. section 8-135. 
1, Bank learns that F2 has combine \#1 and seeks replevin. Who wins between Bank and F2?

Bank wins. The default rule of section 9-315(a)(1) applies again. Section 9-320(a) (buyer-in-ordinary-course rule) is no help to F2. Remember, section 9-320(a) has two requirements: (1) buyer must be a buyer in the ordinary course; and (2) F2's seller must have created the security interest in combine \#1. ${ }^{137}$ While F2 is a buyer in the ordinary course because it bought from someone in the business of selling goods of that kind, Dealer, who is the seller, did not create the security interest. F1 created the security interest. Thus, F2 cannot satisfy both requirements of section 9-320(a), Bank's security interest is not cut off, and F2 is subject to it. What is F2's remedy? Again, F2 has a cause of action against Dealer under section 2-312 for breach of the warranty of title. Dealer could have easily prevented this problem. Dealer should have checked to see if anyone had filed a financing statement against F1 and combine \#1. What if Bank cannot locate combine \#1? Bank will likely have a cause of action against Dealer for purchasing (by taking it on trade) combine \#1 which was subject to the security interest. Conversion is a real possibility depending upon the elements needed to establish it. Again, Dealer should bear the risk of loss.

\section{BUYERS OF GOODS FROM MERCHANTS WHO SELL GOODS ENTRUSTED TO THEM}

Under the entrustment doctrine of UCC section 2-403, a buyer in the ordinary course who buys from a merchant who deals in the type of goods sold can get better title than the seller had. ${ }^{138}$ This rule is illustrated in the following simple hypo:

On January 2, O leaves watch to be repaired with Jeweler (J) who sells and repairs watches. $\mathrm{O}$ does not authorize $\mathrm{J}$ to sell the watch. On

137. See U.C.C. § 9-320(a). Buyer in ordinary course is defined in U.C.C. § 1-201(b)(9). See infra note 183 and accompanying text.

138. See UCC section 2-403, which provides, in relevant part:

(2) Any entrusting of possession of goods to a merchant who deals in goods of that kind gives him power to transfer all rights of the entruster to a buyer in ordinary course of business.

(3) "Entrusting" includes any delivery and any acquiescence in retention of possession regardless of any condition expressed between the parties to the delivery or acquiescence and regardless of whether the procurement of the entrusting or the possessor's disposition of the goods have been such as to be larcenous under the criminal law.

U.C.C. $\S 2-403(2),(3)$. 
January 10, J sells watch to Heather $(\mathrm{H})$. On February 1, O seeks to replevy the watch or sue $\mathrm{H}$ for conversion. Can $\mathrm{H}$ keep the watch?

The relevant UCC sections are: 2-403(2)-(3), ${ }^{139} 1-201(\mathrm{~b})(9),{ }^{140}$ and $2-$ 104(1). ${ }^{141}$ To win, $\mathrm{H}$ must show that an entrustment of goods occurred, that $J$ sold the watch and was a merchant who dealt with watches, and that she was a buyer in the ordinary course of business. If she establishes these three things, she wins even though $J$ is in effect a thief because he sold the watch without authority. $\mathrm{H}$ will almost always win.

In general, the entrustment doctrine is a balancing of the risk of loss between owners and buyers. It protects innocent buyers who buy from someone who has possession of the good and is in the business of selling goods of the kind. $\mathrm{O}$, the entruster, is in the best position to have prevented the problem by determining the honesty of the dealer. This rule promotes the free flow of commerce. Now consider this new hypo:

January 2, O grants Bank a perfected security interest in her watch. February 3, O leaves watch to be repaired with Jeweler (J) who sells and repairs watches. $\mathrm{O}$ does not authorize $\mathrm{J}$ to sell the watch. February 10 , J sells watch to $\mathrm{H}$. February $15, \mathrm{O}$ defaults on her obligation to Bank. March 1, Bank seeks to replevy the watch or sue $\mathrm{H}$ for conversion. Who wins between $\mathrm{H}$ and Bank?

Here, it appears that $\mathrm{H}$ will lose to Bank. Comment four to UCC section 2-403 states: "Except as provided in subsection (1), the rights of purchasers other than buyers in ordinary course are left to the Articles on Secured Transactions [Article 9] ...."142 Section 2-403(1) states: “A purchaser of goods acquires all title which his transferor had or had power to transfer except that a purchaser of a limited interest acquires rights only to the extent of the interest purchased."143 And, UCC section 2-403(2) gives the merchant the power to sell all the "rights of the entruster" to a buyer in the ordinary course. Section 9-315(a)(1) provides that except as otherwise provided by Article 9 or section 2403(2), a security interest continues in collateral notwithstanding sale or

139. These subsections explain the entrustment rule and define entrustment.

140. This section defines a buyer in the ordinary course.

141. This section defines a merchant.

142. U.C.C. $\$ 2-403 \mathrm{cmt} .4$.

143. The second and third sentences of section 2-403(1) deal with situations where a person obtains voidable title in "transactions of purchase." The person with voidable title has the power to pass good title to a good faith purchaser. This rule does not apply to our hypo because J did not obtain the watch in a transaction of purchase, U.C.C. $\S 1-201(29-30)$, but it was entrusted to J. Thus, section 2-403(2) is the relevant section. 
exchange unless the secured party authorized the disposition. Section 9320 (a) does not help $\mathrm{H}$ even though she is a buyer in ordinary course because $\mathrm{J}$ did not create the security interest involved. What about section 2-403(2)? Section 2-403(2) gives the merchant the power to transfer "all of the entruster's rights." Because $\mathrm{O}$, not $\mathrm{J}$, created the security interest in the watch, her rights in the watch are subject to the perfected security interest. A buyer takes the rights that merchant has the power to transfer. ${ }^{144}$ What is the policy justification for the risk of loss rule found in UCC section 2-403(2)? Because J did not create the security interest, this result is consistent with section 9-320(a) that was considered in Hypo 3, supra Part II.B.

If Bank knew that $\mathrm{O}$ had taken the watch to $\mathrm{J}$, it is possible Bank's acquiescence constituted entrustment by Bank and $\mathrm{J}$ then had the power to transfer all the rights of the entruster. ${ }^{145}$ Also, $\mathrm{H}$ could argue Bank was estopped from asserting its security interest because of the acquiescence.

Hammer v. Thompson ${ }^{146}$ deals with a unique entrustment issue. In Hammer, a person other than the owner of cattle had physical possession of the cattle, an "order buyer." 147 The "order buyer" allegedly sold cattle without the owners' authority. ${ }^{148}$ The court dealt with whether the entrustment doctrine of UCC section 2-403 applied and, if so, how the requirements were applied to the facts. ${ }^{149}$

A key question in cases where an owner's goods are sold by another who had physical possession is what is the legal relationship between the alleged owner of the goods and the seller? At least three possibilities exist: bailment, consignment, or creditor-debtor (unpaid seller and buyer). The UCC handles these differently. With one exception, Article 9 does not deal with true consignments ${ }^{150}$ and does not cover true bailments. ${ }^{151}$ A bailment can be considered entrustment under section 2403(3) making section 2-403(2) applicable. ${ }^{152}$

In Hammer, the owner placed cattle with Thompson for grazing on pasture land. ${ }^{153}$ Thompson sold the cattle to Morris who transferred them

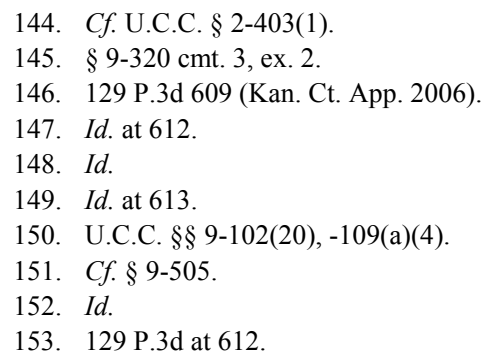


to Hunt who transferred them to Tyson Foods. ${ }^{154}$ The owner was not paid and sued Morris, Hunt, and Tyson in conversion. ${ }^{155}$ The court examined the three requirements of section 2-403(2): did the owner entrust the goods; was Thompson a merchant that deals with cattle; and was Morris a buyer in ordinary course? ${ }^{156}$ As to the merchant issue, the court reviewed the somewhat unique Kansas cases on the definition of merchant under section 2-104(1), Decatur Cooperative Ass'n $v$. Urban, ${ }^{157}$ and Musil v. Hendrich ${ }^{158}$ In Decatur, a farmer was held not to be a merchant for purposes of the statute of frauds' merchant rule under U.C.C. section 2-201. ${ }^{159}$ The court determined that the farmer was not a merchant because he did not "deal" in wheat and did not have any special knowledge of the practices or sales of wheat. ${ }^{160}$ He simply sold his own crop locally for cash. In Musil, a hog farmer was held to be a merchant for purposes of applying the implied warranty of merchantability under U.C.C. section 2-314. ${ }^{161}$ Applying the same test of Decatur it was clear that farmer was a dealer in hogs. ${ }^{162} \mathrm{He}$ had been in the business for more than thirty years and was selling fifty to one hundred hogs a month. ${ }^{163}$ These cases were not directly applicable to U.C.C. section 2-403(2) in that they did not specifically focus on the requirement that the merchant must be a person "who deals in goods of that kind."

In Hammer, Thompson was described as an "order buyer" who acts as a middle person between a seller and buyer. ${ }^{164}$ The issue was whether an "order buyer" can be a merchant that "deals in goods of that kind." The Kansas courts have not addressed this issue, but K.S.A. section 471804(c) defines "livestock dealer." In part, the statute provides that a

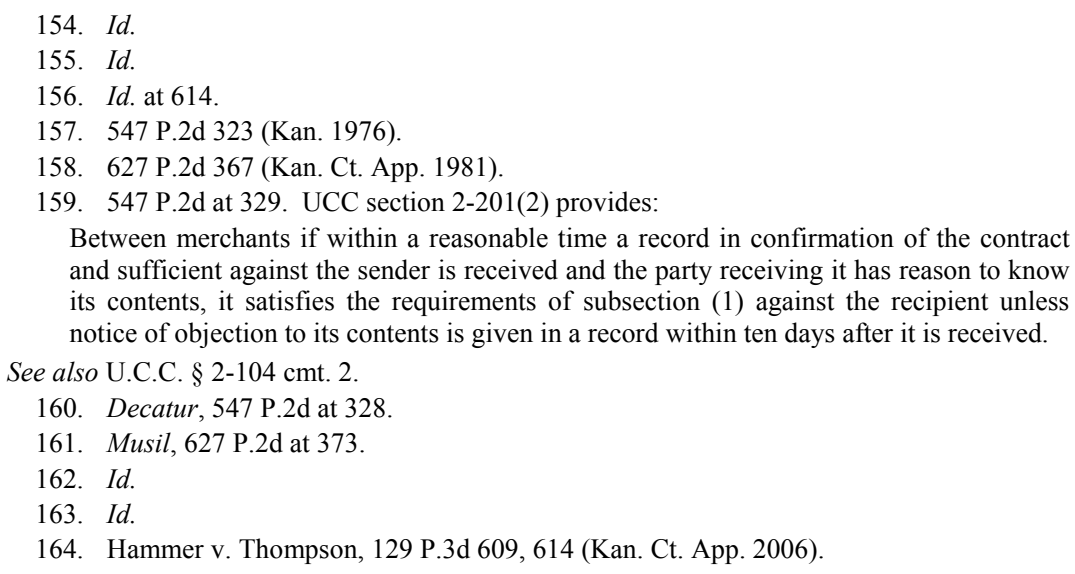


person is a dealer if the person sells as an agent. ${ }^{165}$ It would appear that this definition would cover an "order buyer." "166 And, the court found instructive the Washington case of Heinrich v. Titus-Will Sales, which held a person did not have to possess an inventory to qualify as a merchant under UCC section 2-403(2). ${ }^{167}$

The owner in Hammer asserted that Thompson was not an order buyer, but a person who intended to run growing lots. ${ }^{168}$ Morris and the other buyers, on the other hand, asserted that Thompson was a merchant dealing in cattle, and qualified as a merchant under section 2-403(2). ${ }^{169}$ The trial court in Hammer held that whether Thompson was a merchant was a matter of law and that Thompson was a merchant. ${ }^{170}$ This holding was reversed in part by the Kansas Court of Appeals, which held that the issue was a mixed question of law and fact. ${ }^{171}$ "Whether there exist circumstances to constitute merchant status is a question of fact. But whether those facts that are determined constitute a person as a merchant is a question of law." 172 The appellate court then determined that there was no dispute as to the fact that Thompson entered into a number of sales that showed he was a dealer. ${ }^{173}$ Thus, the trial court did not err in finding Thompson was a merchant as a matter of law.

The next question faced was whether Morris qualified as a buyer in ordinary course of business. ${ }^{174}$ UCC section 1-201(9) provides in part that a buyer in ordinary course of business is a person "that buys goods in good faith, without knowledge that the sale violates the rights of another person in the goods, and in the ordinary course from a person, other than a pawnbroker, in the business of selling goods of that kind." ${ }^{175}$ The appellate court held that there was a material issue of fact as to whether Morris was a buyer in ordinary course because the evidence did not show Morris acted in good faith. ${ }^{176}$ More specifically, the issue was whether Morris followed reasonable commercial standards of fair dealing in the cattle trade. UCC section 2-103(1) provides: "In this article unless

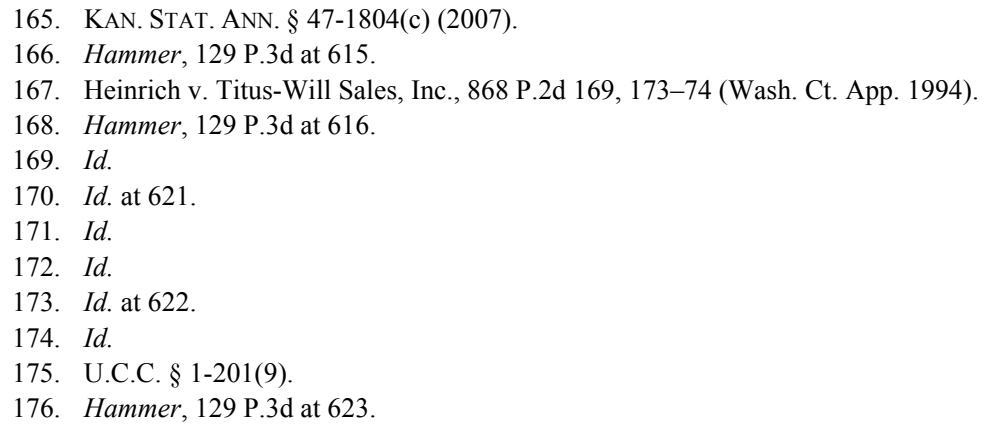


the context otherwise requires: (b) 'Good faith' in the case of a merchant means honesty in fact and the observance of reasonable commercial standards of fair dealing in the trade." ordinary course from a merchant who deals with goods of that kind, the sale of entrusted goods to Morris gives him owner's title, which was an unrestricted good title. Any subsequent buyer from Morris, regardless of whether that buyer could qualify as a buyer in ordinary course, obtains the benefit of Morris's title. Conversely, if Morris cannot qualify under UCC section 2-403(2), Morris takes Thompson's title, which was no title, and all subsequent purchasers take subject to owner's claims under UCC section 2-403(1).

Another situation where the entrustment issue arises is when a farmer stores grain in an elevator and receives a warehouse receipt. When farmer goes to sell his grain, the elevator is bankrupt and does not have enough grain to satisfy all of the people holding valid and enforceable warehouse receipts. Farmer learns that elevator has sold almost all of its grain to Archer-Daniels Midland Company (ADM). Can farmer get its grain from ADM? UCC section 7-205 provides: "A buyer in ordinary course of business of fungible goods sold and delivered by a warehouse that is also in the business of buying and selling such goods takes the goods free of any claim under a warehouse receipt even if the receipt is negotiable and has been duly negotiated."178 This means that a farmer who has stored grain as well as a person who holds a negotiable warehouse receipt will not be able to recover from a qualified buyer from a warehouse that fails, even if the farmer can trace his or her grain to the buyer. This is the entrustment concept of UCC section 2-403(2). Remember, the goods must be sold and delivered. UCC section 1201(b)(15) defines deliver with respect to electronic documents of title, negotiable instruments, tangible documents of title and chattel paper, but not goods. Delivery for the negotiable instruments, tangible documents of title and chattel paper means "voluntary transfer of possession."179 Possession is not defined in the UCC. No definition of delivery exists for goods in UCC section 1-201 or Article 7. Thus, pursuant to UCC section 1-103(b), law other than the UCC controls.

The delivery issue can arise under UCC section 7-205 in at least two different situations. For example, fungible grain has been purchased and paid for, but is put in a rail car leased by the elevator. The grain is to be

177. U.C.C. § 2-103(1).

178. U.C.C. $§ 7-205$; see also $§ \S 7-501,-503$.

179. $\S 1-201(b)(15)$. 
transported to the buyer's location. Is this delivery? Has risk of loss shifted to the buyer under UCC section 2-509? What if the grain is deposited in a rail car that belongs to the buyer and the buyer's name is on the car but the car is located on rail spur belonging to the seller? What if the grain was deposited in a train car of a commercial rail company?

\section{Purchase of FARm Products SubJect to A Perfected SECURITY INTEREST}

Under Article 9, the default rule of UCC section 9-315(a)(1) applies to the sale of farm products. And, unless the secured party authorized the sale of farm products, buyer buys subject to a perfected security interest. The buyer in ordinary course rule of UCC section 9-320(a) does not apply to the sale of farm products. This controversial rule, ${ }^{180}$ was hated by buyers of farm products such as elevators and feedlots, and other buyers such as producers of pet food. The buyers, unable to get Article 9 changed at the state level, eventually persuaded Congress to change the rule in $1986 .{ }^{181}$ Congress in effect repealed the farm products rule of former UCC section 9-307 and current UCC section 9-320(a). Comment 4 to UCC section 9-320 provides:

Buyers of Farm Products. This section does not enable a buyer of farm products to take free of a security interest created by the seller, even if the buyer is a buyer in ordinary course of business. However, a buyer of farm products may take free of a security interest under Section 1324 of the Food Security Act of 1985, 7 U.S.C. $§ 1631$.

Congress's purpose in enacting 7 U.S.C. $\S 1631$ was to shift the potential burden of the loss to lenders. After 1986, buyers had no responsibility to search the records to determine whether the farm products they were buying were subject to a perfected security interest.

180. This rule is discussed in many places. See, e.g., Keith G. Meyer, The 9-307(1) Farm Products Puzzle: Its Parts and Its Future, 60 N.D. L. REV. 401 (1984).

181. See, e.g., Drew L. Kershen \& J. Thomas Hardin, Congress Takes Exception to the Farm Products Exception of the UCC: Retroactivity and Preemption, 36 U. KAN. L. REV. 1 (1988); Drew L. Kershen \& J. Thomas Hardin, Congress Takes Exception to the Farm Products Exception of the UCC: Centralized and Presale Notification Systems, 36 U. KAN. L. REV. 383 (1988); Keith G. Meyer, UCC Issues, 8 J. AgRIC. TAX'N \& L. 153 (1986); Keith G. Meyer, Congress's Amendment to the UCC: The Farm Products Rule Change, J. Kan. B. Ass'N, Sept.-Oct. 1996, at 17; Steven W. Sanford, The Reborn Farm Products Exception Under the Food Security Act of 1985, 20 UCC L.J. 3 (1987).

182. U.C.C. \$ 9-320 cmt. 4. 
The secured creditors had the burden to provide notice of the security interest to a potential buyer.

Under 7 U.S.C. $\S 1631(\mathrm{~d})$, the general rule is that the buyer in the ordinary course ${ }^{183}$ takes free of a perfected security interest created by his seller in farm products even though the buyer knows of its existence, and state law provides otherwise unless it has received appropriate notice under subsection (e). ${ }^{184}$ It is important to note that $\S 1631$ applies only to the sale of farm products. ${ }^{185}$ While Article 9's definition is somewhat different, presumably courts will use it by analogy as well as the cases dealing with it. ${ }^{186}$ The cases dealing with Article 9's definition prior to 2001 are particularly relevant in that the definitions at that time were very similar. ${ }^{187}$ Today they are different. ${ }^{188}$ Under subsection (e), a

183. The term "buyer in the ordinary course" is the same term used in the UCC. U.C.C. § 1201(a)(9). However, it is defined differently in 7 U.S.C. $\S 1631(c)(1)$. When one compares the definitions, unlike the UCC definition, buyer's knowledge of a perfected security interest and good faith of the buyer are irrelevant under $\S 1631$. 7 U.S.C. $\S 1631(\mathrm{c})(1)$.

184. 7 U.S.C. $\$ 1631(\mathrm{~d})$.

185. Again, the term farm products is used in both UCC section 9-102(b)(34)-(35) and in 7 U.S.C. $\S 1631$. The term is defined in 7 U.S.C. $\S 1631(\mathrm{c})(5)$. The federal definition has not been updated like Article 9's definition was in 2001. See U.C.C. § 9-102(a)(34)-(35), cmt. 4a (2009).

186. For central filing systems, 9 C.F.R. $\S 205.211$ (a) (2010) provides:

Court decisions under the Uniform Commercial Code (UCC), about the scope of the "farm products" exception in Section 9-307(1) thereof, and interpreting the terms therein, particularly "person engaged in farming operations" which is not defined in the Section, are applicable to an extent in interpreting the Section. The basis of this is the legislative intent of the Section to pre-empt State laws reflecting that "farm products" exception, as shown in the House Committee Report on Pub. L. No. 99-198, 99-271, Part 1, September 13,1985 , at pages 108 et seq.

187. 7 U.S.C. $§ 1631(c)(5)$ states:

The term "farm product" means an agricultural commodity such as wheat, corn, soybeans, or a species of livestock such as cattle, hogs, sheep, horses, or poultry used or produced in farming operations, or a product of such crop or livestock in its unmanufactured state (such as ginned cotton, wool-clip, maple syrup, milk, and eggs), that is in the possession of a person engaged in farming operations.

Former Article 9 in $§ 9-109$ defined farm products as follows:

[C]rops or livestock or supplies used or produced in farming operations or if they are products of crops or livestock in their unmanufactured states (such as ginned cotton, wool-clip, maple syrup, milk and eggs), and if they are in the possession of a debtor engaged in raising, fattening, grazing or other farming operations. If goods are farm products they are neither equipment nor inventory.

Compare U.C.C. § 9-109(3) (1999) (defining farm products to require that the debtor have possession), with U.C.C. § 9-102(a)(35) (2009) (expanding the definition to include reference to aquaculture). For a general discussion of the term "farm products," see Meyer, supra note 180, at $412-15$.

Some courts narrowly construed the term "farming operation" within these definitions by limiting it to a traditional farming operation, while others defined it more broadly. Compare K.L. Smith Enter. v. United Bank of Denver, N.A., 2 B.R. 280, 283-84 (Bankr. D. Colo. 1980) (construing farming operation broadly), and In re Charolais Breeding Ranches, Ltd., 20 U.C.C. Rep. Serv. (CBC) 193, 196-97 (Bankr. W.D. Wis. 1976) (construing farming operation broadly), with 
buyer of farm products takes subject to a security interest created by the seller if appropriate written notice was received from the lender or seller, or if the state has a "central filing system," and the buyer has received the appropriate notice from the Secretary of State. ${ }^{189}$ At least nineteen states have a "Central Filing System." 190 The same basic rule applies to commission merchants or selling agents. They will not be subject to a perfected security interest even if they know of its existence, if they sell

John M. Saums, Inc. v. Blease, 24 U.C.C. Rep. Serv. (CBC) 450, 453 (Bankr. D. N.J. 1978) (stating that " $\mathrm{t}$ ]o be [engaged in] farming operations the debtor must actually be engaged in farming, not farm related or farm support or farm like activities"), and In re Collins, 3 B.R. 144, 149 (Bankr. D. S.C. 1980) (holding that "farming operations' is to be narrowly construed").

Part-time farmers can operate a "farming operation." See 11 U.S.C. § 101(18) (1994) (defining farmer based on percentage of income); see also Blease, 24 U.C.C. Rep. Serv. at 454 (holding that "equipment must be used directly to perform tasks customarily done on farms"); Armstrong v. Corn Belt Bank, 55 B.R. 755, 761 (D. Ill. 1985) (stating that rent income does not make lessor a farmer); In re Dakota Lay'd Eggs, 57 B.R. 648, 656 (Bankr. D. N.D. 1986) (holding that "the determination must be made by considering the character of the business" and the source of its income).

For cases dealing with breeding syndicators, see Estate of A.R. Levis v. Blankinship-Cooper, Inc., 43 B.R. 231, 236 (Bankr. N.D. Tex. 1984) (holding that breeding rights in a horse were properly characterized as goods); In re Bob Schwermer \& Assocs., Inc., 27 B.R. 304, 308 (Bankr. N.D. Ill. 1983) (stating that race horses are not farm products); North Ridge Farms, Inc. v. Trimble, 37 U.C.C. Rep. Serv. (CBC) 1280, 1286 (Ky. Ct. App. 1983) (stating that horse owners who race horses do not run a farming operation).

188. U.C.C. § 9-102(a)(34)-(35) provides:

(34) "Farm products" means goods, other than standing timber, with respect to which the debtor is engaged in a farming operation and which are:

(A) crops grown, growing, or to be grown, including:

(i) crops produced on trees, vines, and bushes; and

(ii) aquatic goods produced in aquacultural operations;

(B) livestock, born or unborn, including aquatic goods produced in aquacultural operations;

(C) supplies used or produced in a farming operation; or

(D) products of crops or livestock in their unmanufactured states.

(35) "Farming operation" means raising, cultivating, propagating, fattening, grazing, or any other farming, livestock, or aquacultural operation.

Compare U.C.C. § 9-109(3) (1999) (defining farm products to require that the debtor have possession) with U.C.C. § 9-102(a)(35) (2009) (expanding the definition to include reference to aquaculture). Also, the issue of whether a good is a farm product or equipment or inventory has been often litigated. 7 U.S.C. $\S 1631(\mathrm{c})(5)$ 's definition of farm product is found supra note 187.

189. 7 U.S.C. $\S 1631(\mathrm{e})(2006)$.

190. Alaska Stat. $\S \S 45.29 .501,44.37 .027$ (West 2007); Colo. Rev. STat. $§ 4-9.5-104$ (West 2002); IdAHO CODE ANN. §§ 28-9-523, 28-9-501 (West 2006); LA. ReV. STAT. ANN. § 3:3655 (2003); Me. ReV. Stat. AnN. tit. 5, § 90-A (2002); MinN. Stat. AnN. § 336A.04 (2010 Supp.); Miss. CODE ANN. § 75-9-501 (West 2004); MONT. CODE ANN. § 2-15-401(1)(n) (West 2009); NeB. REV. ST. § 52-1301 (West 2009); N.H. REV. STAT. § 439:3(I) (West 2002); N.M. STAT. ANN. § 5613-4 (West 2003); N.D. CENT. CODE, §§ 54-09-09, 41-09-73 (2008); OKL. STAT. ANN. tit. 12a, § 19-320.6 (West 2001); OR. REv. STAT. ANN. $\$ 80.106$ (West 2003); S.D. Codified LAWS $§ 57$ A-9525.3 (2004); UTAH CODE ANN. § 70A-9a-320(6)(b) (West 2004); VT. STAT. ANN. §§ 9-501, 9-302 (2007); W.VA. Code AnN. 46-9-523 (West 2002 Supp.); and Wyo. Stat. AnN. § 34-21-1102 (2007). 
in the ordinary course of business a farm product subject to a perfected security interest and have not received an appropriate notice. ${ }^{191}$

7 U.S.C. $\S 1631$ preempts the states from legislating in this area. ${ }^{192}$ States cannot attempt to further protect buyers or lenders. Under the statute, states have the power to choose only: (1) what constitutes receipt $;{ }^{193}$ and (2) one of two notice alternatives developed in detail by Congress. ${ }^{194}$ Kansas implemented Alternative One: Written Notice Provided by Lender or Seller. Under this option, as noted above, if the buyer receives, within one year before the sale, a proper written notice from the lender or seller, and the buyer does not comply with payment instructions in the notice, the buyer takes subject to a perfected security interest in farm products created by the seller.

How does Lender know what buyer to notify? Lender may require in the security agreement that the borrower supply a list of buyer names. If Debtor sells to a buyer not on the list and neither notifies the Lender seven days before the sale nor remits the proceeds within ten days after the sale, the farmer shall be fined $\$ 5000$ or fifteen percent of the value of the farm products, whichever is greater. Many creditors have obtained Debtor's permission to send blanket notices to potential buyers of farm products. Some have sent blanket notices without obtaining Debtors' express consent.

What if the secured party sends a written notice to the buyer but the notice does not contain the required information? Courts are split as to whether the minor-error rule, set forth in 7 U.S.C. $\S 1631(\mathrm{c})(4)(\mathrm{H})$ dealing with a "central filing system," applies to direct notices given in states that do not have a central filing system. The so-called minor-error rule provides that an "effective financing statement" containing errors is still effective if the errors are "not seriously misleading."195 First

191. 7 U.S.C. $\S 1631(\mathrm{~g})$. Commission merchant is defined in $\S 1631(\mathrm{c})(3)$ and selling agent in $\S$ 1631(c)(8). For an interesting case, see Deere \& Co. v. Miller-Godley Auction Co., 549 S.E.2d 762 (Ga. Ct. App. 2001). This case involved an auctioneer. Id. at 763. An auctioneer who sells a good subject to a perfected security interest is liable for conversion. Id. at 766 . The Court notes that every other state that has considered this issue has concluded that the auctioneer can more easily search the records than a prospective buyer can. Id. at 765 . Moreover, if third parties are permitted to ignore filed financing statements, Article 9's notice system is rendered a nullity. Id. Accordingly, the auctioneer must search public records for filed financing statements. Id. at 765-66.

Remember that if the auctioneer is selling farm products, the transaction should be covered by 7 U.S.C. § 1631. The auctioneer should be considered either a commission merchant or a selling agent, as defined in 7 U.S.C. $\S 1631(\mathrm{c})(3)$ and (8). The auctioneer will normally be protected unless he receives proper notice of the security interest. 7 U.S.C. $\S 1631(\mathrm{~g})$.

192. 7 U.S.C. $\S 1631(d)(2006)$.

193. §1631(f), (g)(3).

194. $\S 1631(\mathrm{~g})(2)(\mathrm{C})-(\mathrm{D})$.

195. $\S 1631(\mathrm{c})(4)(\mathrm{H})$. 
National Bank \& Trust v. Miami County Cooperative Ass' $n^{196}$ applies a substantial compliance test to direct notice requirements notwithstanding no reference to a minor error rule in the requirements dealing with direct notice. ${ }^{197}$ The court points out that nothing in the legislative history of $\S 1631$ indicates that Congress intentionally omitted the minor error rule in the direct notice option and the legislative history seems to suggest that the two notice systems were intended to produce as uniform results as possible. Accordingly, it was appropriate to apply the minor error rule to the direct notice option. Thus, the court concluded that, from all the information provided the buyer, the buyer was not misled. ${ }^{198}$ Buyer could determine from the notice who would be selling the farm products and what specific farm products were subject to the secured party's security interest. ${ }^{199}$ In other words, substance rather than form controlled. Farm Credit Midsouth, PCA v. Farm Fresh Catfish Co. adopts a strict construction standard and concludes that the statute dealing with direct notice says nothing about minor errors therefore none applies. $^{200}$ This court specifically rejects the Kansas court's construction of the direct notice requirements in Miami County Cooperative Ass ' $n .{ }^{201}$ From my perspective, the Kansas court got it right!

To make sure that we have a basic grasp of some of the quirks of 7 U.S.C. $\S 1631$, let us consider some basic hypotheticals.

Section 1631 Hypo \#1: Feedlot sale of cattle held for a short period of time:

Bank has a perfected security interest in all cattle in Jones Feedlot. January 2, Jones Feedlot buys fifty head of distressed cattle (very rough

196. 897 P.2d 144, 152 (Kan. 1995).

197. The court points out that nothing in the legislative history of 1631 indicates that Congress intentionally omitted the minor-error rule in the direct notice option and the legislative history seems to suggest that the two notice systems should be treated to produce as uniform results as possible. Accordingly, it was appropriate to apply the minor-error rule to the direct notice option.

198. First Nat'l Bank \& Trust, 897 P.2d at 152.

199. See id.

200. 371 F.3d 450, 453 (8th Cir. 2004). See also First State Bank of Athens Mabank Branch v. Purina Ag Capital Corp., 113 S.W.3d 1 (Tex. Ct. App. 1999). Pioneer Hi-Bred Intern., Inc. v. Keybank Nat'l Ass'n deals with adequate notice under the direct or written notice option. 742 N.E.2d 967 (Ind. Ct. App. 2001). After farmers defaulted on loans secured by their real and personal property, a secured creditor brought an action against corporation that had entered into a seed corn production agreement with farmers, alleging that the corporation had converted the collateral when it paid the farmers and their supplier with the proceeds of the seed corn sale. Id. at 967. The Court of Appeals held that the corporation received notice of the creditor's security interest within one year of seed corn sale and thus was subject to the secured creditor's perfected security interest in the proceeds from the sale. Id. at 972 .

201. Farm Credit Midsouth, 371 F.3d at 453. 
cattle). January 20, Feedlot after having the fifty head on a special diet, sells the rejuvenated cattle that Feedlot had purchased on January 2 to Rancher. February 10, Feedlot defaults on its Bank loan. Can Bank repossess the 50 head of cattle from Rancher? Does 7 U.S.C. $\S 1631$ apply?

For 7 U.S.C. $§ 1631$ to apply to the sale of the cattle, Jones Feedlot must be selling farm products. This means that Jones Feedlot must be engaged in a farming operation and have possession of the livestock in the farming operation. ${ }^{202}$ While running a feedlot is a farming operation, cattle trading is not. ${ }^{203}$ Normally, a feedlot operator would not buy and sell cattle so quickly. The issue is whether this quick turn around sale makes Feedlot a trader and not an operation involved in the raising and fattening of animals. If Feedlot never intended to fatten the fifty head and only intended to turn the cattle, it is not a farming operation. ${ }^{204}$

Section 1631 Hypo \#2: what impact does actual knowledge of a security interest have?

Bank has a perfected security interest in all of Farmer's crops. July 1, Bank calls Elevator and specifically tells Elevator that Bank has a

202. See supra note 160 and accompanying text.

203. See Sec. Nat'l Bank v. Belleville Livestock Comm'n Co., 619 F.2d 840, 850 (10th Cir. 1979) (holding that because the debtor was a cattle feeder rather than a cattle trader, his cattle should have been considered "farm products"); Farmers State Bank v. Webel, 446 N.E.2d 525, 529 (Ill. App. Ct. 1983) (holding that a business that bought and sold feeder pigs was a marketing agency within the meaning of the comment to UCC section 9-109, and that the business was therefore selling inventory and not farm products); see also Swift \& Co. v. Jamestown Nat'l Bank, 426 F.2d 1099, 1102 (8th Cir. 1970) (holding that the plaintiff cattle-owner's “'fattening' of livestock [fell] within the explicit terms of [U.C.C. § 9-109(3)]"); Burlington Nat'l Bank v. Strauss, 184 N.W.2d 122, 125 (Wis. Ct. App. 1971) (holding that "[1]ivestock whether it makes sense to a dairy farmer or not, is classified as 'farm products' and not as inventory by sec. 409.109(3)" of the Wisconsin code); cf. Mountain Credit v. Michiana Lumber \& Supply, Inc., 498 P.2d 967, 969 (Colo. Ct. App. 1972) (holding that a logging operation was not a farming operation); In re Maike, 77 B.R. 832, 839 (Bankr. D. Kan. 1987) (holding that a puppy kennel was a farming operation).

It should also be noted that cattle cease to be classified as farm products and become part of the packer's inventory after they have been slaughtered and packed, notwithstanding the fact that there was an oral agreement between the seller and the packer that title would not pass and price would not be determined until carcass grade was determined. First Nat'l Bank v. Smoker, 286 N.E.2d 203, 209 (Ind. Ct. App. 1972). See also Stowers v. Mahon (In re Samuels \& Co.), 526 F.2d 1238 (5th Cir. 1976); In re Underbakke, 60 B.R. 705, 708 (Iowa 1986) (concluding that farm products include milk). Former UCC section 9-109(3) defines farm products to include milk, and read together with section 522(b)(1) of the Bankruptcy Code, this section leads to the conclusion that a secured creditor who has a perfected security interest in the debtor's cows and their milk pre-petition has a continuing interest in the milk produced post-petition. 11 U.S.C. § 522(b)(1) (1998); U.C.C. § 9-109(3) (1999). Revised Article 9 does not change this result.

204. See Sec. Nat'l Bank, 619 F.2d at 850 (factual inquiry as to whether operation is engaged in cattle trading as opposed to cattle feeding; typical feeding period is sixty to ninety days unless cattle already near sale weight). 
perfected security interest in all of Farmer's crops and when Farmer sells any crops it must issue a joint-payee check. July 5, Farmer sells crops to Elevator. Elevator did not cut a joint-payee check. Farmer defaults and Bank sues Elevator in conversion. Who wins?

Again, under 7 U.S.C. $§ 1631(d)$, unless a buyer has notice under (e), a buyer who in the ordinary course buys farm products from a seller who created the security interest and is engaged in a farming operation takes free of a security interest even if it is perfected and buyer knows of its existence. ${ }^{205}$ Here the crops are farm products, seller is engaged in a farming operation, and Elevator buys the grain in the ordinary course of its business. The issue is did Elevator have notice and is it a buyer in the ordinary course. Assume this hypo occurred in a state that has the written direct notice alternative of 7 U.S.C. $\S 1631(\mathrm{e})(1)$, Elevator was not given proper notice. Bank is required to give an appropriate written notice within one year of the sale. ${ }^{206}$ While Elevator had actual knowledge of Bank's security interest and knew that Bank was not consenting to the sale free of a security interest unless a joint-payee check was issued, $\S 1631(\mathrm{e})(1)$ requires written notice. ${ }^{207}$ None was given.

Is Elevator a buyer in the ordinary course of business? Under the UCC definition, Elevator would not be. UCC section 1-201(9) defines a buyer in the ordinary course of business in part as "a person that buys goods in good faith, without knowledge that the sale violates the rights of another party to the goods." 208 Here Elevator had actual knowledge of the security interest and knew that Bank was not agreeing to the sale of

\footnotetext{
205. 7 U.S.C. § $1631(\mathrm{~d})$.
}

206. See, e.g., Pioneer Hi-Bred Intern. Inc. v. Keybank Nat'l Ass'n, 742 N.E.2d 967, 972 (Ind. Ct. App. 2001).

207. For a Kansas case that has 7 U.S.C. $\S 1631$ overtones, see Ag Servs. of Am., Inc. v. DeBruce Grain, Inc., 19 P.3d 188 (Kan. Ct. App. 2001).

208. UCC section 1-201(b)(20) defines good faith as "except as otherwise provided in Article 5 ... honesty in fact and the observance of reasonable commercial standards of fair dealing." Comment 3 to UCC section 9-320(a) dealing with the buyer in the ordinary course of business speaks to the point of knowledge of a security interest and good faith.

The definition of "buyer in ordinary course of business" in UCC section 1-201 restricts its application to buyers "from a person, other than a pawnbroker, in the business of selling goods of that kind." Thus subsection (a) applies primarily to inventory collateral. The subsection further excludes from its operation buyers of "farm products" (defined in UCC section 9-102) from a person engaged in farming operations. The buyer in ordinary course of business is defined as one who buys goods "in good faith, without knowledge that the sale violates the rights of another person in the goods." Subsection (a) provides that such a buyer takes free of a security interest, even though perfected, and even though the buyer knows the security interest exists. Reading the definition together with the rule of law results in the buyer's taking free if the buyer merely knows that a security interest covers the goods; but taking subject if the buyer knows, in addition, that the sale violates a term in an agreement with the secured party. 
the grain free of the security interest. Also, Elevator would probably not have acted in good faith because of its actual knowledge of Bank's perfected security interest and that the sale was not authorized by Bank. However, unlike under the UCC, the definition of a buyer in the ordinary course has no knowledge or good-faith requirement. Thus, it appears that absent the establishment of a contract between Elevator and Bank dealing with the sale of the grain, the Elevator takes free of Bank's security interest. It appears that estoppel and equitable principles like the so-called clean-hands doctrine do not apply. Doubtless, courts would have trouble applying the minor-error test of Miami County Cooperative in that no written notice of any kind was given. ${ }^{209}$

Section 1631 Hypo \#3: What should a buyer do when it receives inadequate notice?

FSA has a perfected security interest (PSI) in Farmer's (F) crops, including all wheat. FSA sends a letter to a number of elevators that states FSA has a PSI in all F's wheat, lists F's correct name and address, and directs Elevator to issue a joint-payee check to F and FSA. What are Elevator's options?

Upon receipt of the notice, Elevator could tell $\mathrm{F}$ of the notice and get F's permission to issue a joint-payee check when F sells wheat. Another possibility is to call Bank and tell them the notice is inadequate and if an adequate notice is not sent, it will issue a single-payee check to $F$ when he sells. The other possibilities are to make no efforts to contact anyone and either issue a check only in the name of $\mathrm{F}$ or issue a joint-payee check. Certainly, if it is clear that the notice is inadequate, the buyer had no responsibility to issue a joint-payee check. This probably violates F's right to receive the money.

On these limited facts, it appears that, unless a minor-error rule is applied, the letter does not satisfy the requirements of 7 U.S.C. $\S$ 1631(e)(1). Certainly, if it is clear that the notice is inadequate, the buyer had no responsibility to issue a joint-payee check. Yet, others on these facts have issued multiple-payee checks that have caused significant difficulties in the farmer getting the check cashed.

Most of the problems with the direct-notice system can be avoided by a state adopting the so-called "central filing system." 110 In a 1986

209. First Nat'l Bank \& Trust v. Miami County Coop. Ass'n, 897 P.2d 144, 152 (Kan. 1995). See supra notes 195-200 and accompanying text.

210. See 7 U.S.C. § 1631(b)(2); see also Arthur H. Travers \& John L. McCabe, A Central Filing System for Financing Statements, CoLO. LaW., Sept. 1999, at 5. 
Kansas Bar Journal article, ${ }^{211}$ I argued that the central filing system was not the best alternative. I have changed my mind. With the maturing of the electronic filing systems and the consumer friendly computer programs, the parties that have a stake in this venture such as the Kansas Banker's Association, the Kansas Feed and Grain Association, the various farm groups such as the Farm Bureau, the Secretary of State's office and the Kansas Bar Association should work together to change the central filing system. This system would have to be approved by the Packers and Stockyard Administration. ${ }^{212}$ The experience of the nearby states of Colorado and Nebraska will be instructive and Minnesota has a rich history as well. While this system is not perfect, it has less chances of errors and litigation possibilities than the direct written notice system does.

As the impact of 7 U.S.C. $\S 1631$ 's notice options are considered, it is important to remember that bank regulators will struggle with how to classify loans secured by crops when the lender does not have an organized method to deal with the notice requirements of 7 U.S.C. $\S$ 1631. Given the current credit crisis, this issue may be more closely examined. Compliance for lenders is certainly more easily established if the state has a "central filing system." And, a "central filing system" arguably deals more effectively with notification of buyers that are in a state other than where the debtor is located. ${ }^{213}$

The following section deals with persons selling grain subject to a security interest when the actual physical person selling the grain did not create the security interest. The problem can arise in a state having a central filing system such as Minnesota and South Dakota as well as in a state like Kansas that has a direct notice system.

\section{VII.SALE OF FARM PRODUCTS SUBJECT TO A PSI Not CREATED BY SELLER}

Two state supreme courts, Minnesota and South Dakota, have considered this issue, reaching different results. The Minnesota Supreme Court, in Fin $\mathrm{Ag}$, Inc. v. Hufnagle, Inc., ${ }^{214}$ was confronted with a situation where a debtor, Buck, who had created a security interest in

211. Keith G. Meyer, Congress's Amendment to the UCC: The Farm Products Rule Change, 55 J. KAN. B. ASS'N 17 (1986).

212. The regulations dealing with the establishment of a central filing system are found at 9 C.F.R. § 205 (2009).

213. See 9 C.F.R. $\S 205.210$ (2009).

214. 720 N.W.2d 579, 580 (Minn. 2006). 
farm products, sold some of the farm products. Some of the farm products subject to the security interest created by Buck were sold by others. ${ }^{215}$ Buck granted Fin a perfected security interest in corn. Buck was engaged in a farming operation and corn is clearly a farm product under Article 9 as well as 7 U.S.C. $\S 1631 .^{216}$ Minnesota is a central filing state for 7 U.S.C. $\S 1631$ purposes and Fin Ag filed a proper effective financing "statement" (EFS) required by the central filing system. Kent Meschke Poultry Farms, Inc. (Meschke), a registered farm products dealer, ${ }^{217}$ received a list of potential sellers, including Buck, whose corn was subject to a security interest. Meschke purchased corn directly from Buck and from the Tookers (employees of Buck and minor children of Buck) who were not listed as having corn subject to a security interest. Tookers, the sellers, apparently represented that they owned the grain. ${ }^{218}$

Buck defaulted on his loan and Fin Ag sued Meschke for conversion of grain subject to its perfected security interest. ${ }^{219}$ Meschke asserted it purchased the grain free of any security interest because the Tookers were not listed as sellers on the 7 U.S.C. $\S 1631$ information received from the Minnesota Secretary of State. ${ }^{220}$ Thus, it did not have notice of the security interest as required by $\S 1631 .^{221}$

The court held Meschke purchased the grain subject to the security interest. $^{222}$ The court had no trouble with the corn sold by Buck himself. $^{223} 7$ U.S.C. $\$ 1631$ controls a priority battle between the secured party and the buyer of farm products. ${ }^{24}$ Under $\S 1631(\mathrm{~d})$ "[e]xcept as provided in subsection (e) of this section ... a buyer who in the ordinary course of business buys a farm product from a seller engaged in farming operations shall take free of a security interest created by the seller ...."225 Buck was engaged in a farming operation, was the seller, and was the person who created the security interest in the farm products sold. $^{226}$ Meschke was a buyer who in the ordinary course purchased

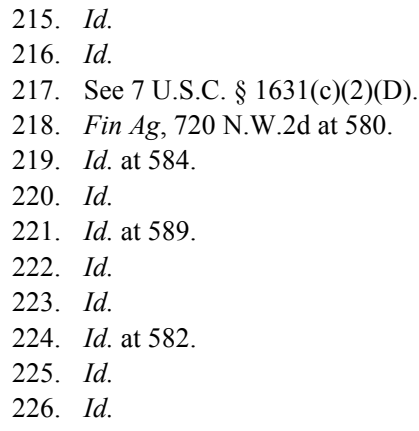


grain but Meschke had received proper notice under (e) of Fin Ag's security interest because Meschke had received a proper list showing Buck's grain was subject to Fin Ag's security interest. ${ }^{227}$

The Tookers sale was much more difficult. Here the court was confronted with a situation where the persons selling the corn did not create the security interest in the corn and were apparently selling corn under their name for an unnamed party (Buck) who had created the security interest. ${ }^{228}$ The court framed the issue as how 7 U.S.C. $\S 1631$ worked in "fronting sales," i.e. farm products that are subject to a security interest created by a debtor who has a third party sell the grain under the third party's name? ? $^{229}$

According to the court, the nondebtor sellers could possibly be treated as either: (1) agents selling on behalf of Buck as an undisclosed principal; (2) as "commission agents" or "selling agents," defined under 7 U.S.C. $\S 1631(c)(3),(8)$; or (3) as owners of corn, selling on their own behalf. ${ }^{230}$ The court applied the general rule of 7 U.S.C. $\S 1631$ that the buyer takes free of a perfected security interest created by his seller unless the buyer received appropriate notice. ${ }^{231}$ The keys are who is the seller and who created the security interest.

The seller could be Buck as an undisclosed principal or the Tookers. Either way, according to the court, Meschke takes subject to Fin Ag's security interest. ${ }^{232}$ If Buck is considered the seller, Meschke received notice of Fin Ag's security interest and took subject to it. ${ }^{233}$ If the Tookers are considered the sellers, Meschke still purchased the corn subject to the security interest. ${ }^{234}$ If they are the owners, they took the corn from Buck subject to the security interest because they were not buyers in the ordinary course. ${ }^{235}$ Moreover, the Tookers did not create the security interest and thus cannot satisfy the requirement that the seller must have created the security interest at issue. ${ }^{236}$ Also, 7 U.S.C. $\S$ 1631(g) dealing with commission merchants and selling agents does not

\footnotetext{
227. Id.

228. Id. at 584 .

229. Id.

230. Id.

231. Id. at 586 .

232. Id. at 587.

233. Id

234. Id.

235. Id.

236. Id.
} 
apply here because the sellers did not register as commission or selling agents as required by 7 U.S.C. $\S 1631 .^{237}$

Lastly, Meschke argued that the grain was inventory in the hands of the Tookers, not farm products, and that he took free of Fin Ag's security interest. $^{238}$ Even if the corn were inventory, section 9-320(a) requires that the seller must have created the security interest. ${ }^{239}$ Tookers did no such thing. ${ }^{240}$ In most conflicts concerning the sale of farm products subject to a security interest, the scoundrel is the farmer and the buyer and the creditor are relatively innocent. This was the case here. Fin Ag and Meschke were treated as innocent parties because each had done all that it could to protect itself.

Two years after Hufnagle was decided, the South Dakota Supreme Court considered 7 U.S.C. $\S 1631$ in three cases dealing with the sale of farm products that were subject to a security interest. The court in effect rejected the Minnesota Supreme Court's approach as to who is a seller. The three are: Fin-Ag, Inc. v. Pipestone Livestock Auction Market, Inc., ${ }^{241}$ Fin-Ag, Inc. v. Watertown Livestock Auction, Inc., ${ }^{242}$ and Fin-Ag, Inc. v. Cimpl's, Inc. ${ }^{243}$ The United States Supreme Court denied certiorari in Pipestone, ${ }^{244}$ but the issues considered in Pipestone are in effect the same issues considered in Watertown and Cimpl's. Each will be discussed in some manner here.

In Fin-Ag, Inc. v. Cimpl's, Inc., Fin-Ag loaned money to the Berwald Brothers, who executed a security agreement granting Fin-Ag a security interest in farm products. ${ }^{245}$ A financing statement (FS) and effective financing statement (EFS) were filed with the Secretary of State. ${ }^{246}$ The FS showed the debtor as "Berwald Partnership" and described the collateral as all livestock and farm products. ${ }^{247}$ The EFS covered farm products such as dairy cattle and milk and listed the debtor as the

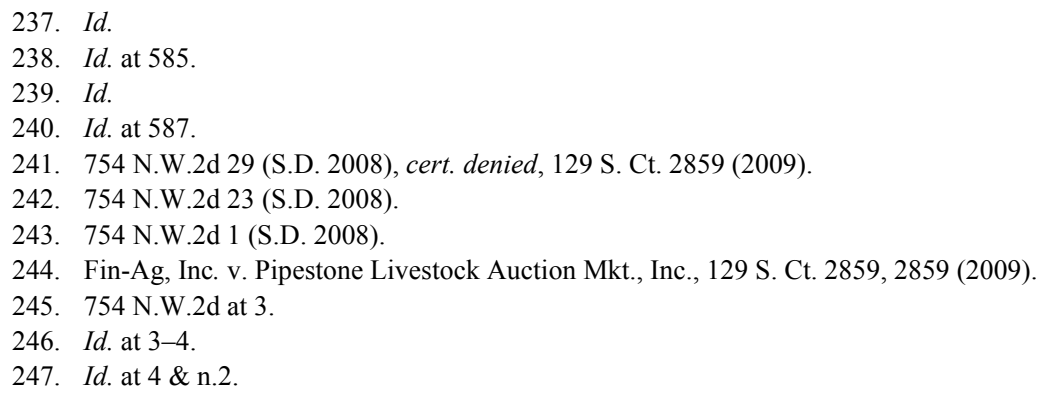


"Berwald Partnership.",248 The security agreement and EFS required joint-payee checks when any cattle were sold. ${ }^{249}$

Cattle subject to the Fin-Ag security interest and belonging to the Berwalds were sold to Cimpl, a packer, who was registered with the Secretary of State's central filing system and received the monthly registry master list showing Fin-Ag's debtors and collateral subject to security interests. ${ }^{250}$ When cattle were delivered to Cimpl, the physical deliverer was issued a receiving ticket. ${ }^{251}$ It showed that the deliveries were made by a Berwald including one of the brothers or the brother's father who was not part of the partnership. ${ }^{252}$ Cimpl was informed that the cattle were being sold by $\mathrm{C} \& \mathrm{M}$ Dairy $(\mathrm{C} \& \mathrm{M}){ }^{253}$ According to the majority opinion, Cimpl did not know that $C \& M$ was a d.b.a. used by two of the Berwald brothers to buy and sell cattle. ${ }^{254}$ After a check of the EFS registry did not disclose $\mathrm{C} \& \mathrm{M}$, Cimpl issued a single payee check to $\mathrm{C} \& \mathrm{M} .^{255}$

The Berwalds defaulted and Fin-Ag sued Cimpl in conversion asserting Cimpl converted Fin-Ag's collateral when it purchased the cattle and did not remit to it any proceeds or list it as a payee. ${ }^{256}$ Fin-Ag essentially made two arguments: (1) 7 U.S.C. $§ 1631$ does not protect Cimpl: because it knew in fact that the seller was the Berwald brothers; and (2) section 1631 protects only those buyers who buy from a seller who created the security interest involved, and Cimpl's seller did not create the security interest. ${ }^{257}$ The majority rejected both arguments. ${ }^{258}$ As to whether the buyer had notice of who the seller was, the majority concluded that the only notice that is important is what was obtained from the filed EFSs and who was on the registry list. ${ }^{259} \mathrm{C} \& \mathrm{M}$ was not listed. $^{260}$ Thus, Cimpl purchased the cattle free of a security interest because C \& M Dairy was not listed in the registry it received from the Secretary of State. ${ }^{261}$

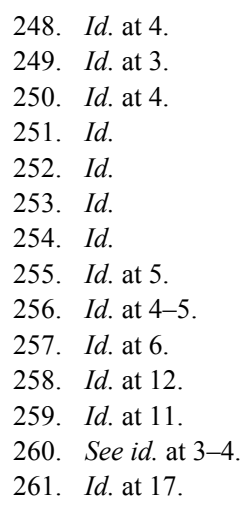


The majority concludes that C \& M Dairy (d.b.a.) is not "a nonexistent entity" as Fin-Ag argued but is a separate debtor that required a separate listing in the central filing system. The majority states that

the applicable rules for the South Dakota central filing system required Fin-Ag to have listed C \& M Dairy [d.b.a] as a separate name on its EFS. The South Dakota Administrative Rules implementing the FSA central filing system provide that the "use of doing business as is considered an additional debtor and shall be listed as such with the elimination of the doing business as."

The court then concluded irrespective of the precise legal status of $\mathrm{C}$ \& M Dairy "it was considered an additional debtor that required a separate listing for purpose of giving notice under the FSA." ${ }^{263}$ Thus, the rule in South Dakota is that buyers have no obligation to check the public records other than the master list for the debtor-seller's name. ${ }^{264}$ In some ways, this conclusion is form over substance, but it is a litmus paper type of test. And, a buyer does not have to worry about dealing with multiple parties claiming a portion of the proceeds of the sale of farm products. The only party entitled to be a payee on the check other than a debtor is a party listed on the master list. ${ }^{265}$

262. Id. at 11 (citing S.D. ADMIN. R. 5:04:04:20 (2009) as "discussing effect of amendment of financing statement to include new debtor").

263. Id.

264. See id.

265. As noted in the text, this approach avoids the so-called hostage checks. Consider the following example: Farmer sells farm products subject to a perfected security interest to Buyer who has received requests from multiple parties to be listed as a payee of the check issued for the sale of Farmer's farm product. The parties requesting to be listed include a secured creditor who has given Buyer proper 7 U.S.C. $\$ 1631$ notice and from others who have not complied with the notice provisions of $\S 1631$. How does Buyer proceed? What if Buyer issues a single payee check to secured creditor? What if Buyer issues a check to multiple payees, including people who have not complied with $\S 1631$, and one person in this group refuses to endorse checks unless they receive a favorable share?

The Commodity Credit Corporation (CCC) faced this problem in the past. In October, 1992, the CCC attempted to deal with multiple payee checks. It issued Notice LP-1489 to ASCS offices. Under this directive, buyers of grain subject to the CCC's perfected security interest had to agree to issue a check payable only in the name of $\mathrm{CCC}$ before $\mathrm{CCC}$ would sign a lien waiver form. Thus, the elevator was required to ignore other creditor notices under $\S 1631$.

The CCC would indemnify the buyers if a creditor holding a superior interest to the $\mathrm{CCC}$ were to sue the buyer. It would only indemnify for the amount of grain specified in CCC Form CCC-6811 which must be signed by producer and is sent to the named buyer. The CCC argued that as a standard practice county ASCS [FSA] offices conduct lien searches and obtain lien waivers from other filed lienholders on the quantity of commodity as collateral for price support loans before a price support loan is made. Accordingly, it has priority over conflicting claims to the grain used as collateral for the loan. To not permit a single payee check would essentially require the producer or the ASCS [FSA] office to do the same task twice, i.e. search the records and obtain lien waivers and 
It is amazing to me that a d.b.a "entity" that is in effect a trade name is required to be listed on the EFS. It appears that South Dakota is the only state to require this. Section 1631 does not define the term "debtor." Under revised Article 9, a financing statement that only provides a trade name for the name of the debtor is legally insufficient and is certainly not required. ${ }^{266}$ Moreover, the brothers signed the security interest creating the security interest. While not considered by the court, it is interesting to speculate whether the omission of the d.b.a. name could be considered a minor error given the factual context as to who physically was doing the selling. Section 1631 does contain a minor error rule in the central filing notice system. The definition of an "effective financing statement" for purposes of a central filing system under 7 U.S.C. $\S 1631$ provides that, "The term effective financing statement means a statement that - ... substantially complies with the requirements of this subparagraph even though it contains minor errors that are not seriously misleading." 267

The majority also stated categorically that the buyer had no duty to investigate the legal status of C \& M Dairy even though most, if not all, of the receiving slips given to the seller showed a Berwald had delivered farm products. ${ }^{268}$ The majority in effect said that because Congress was trying to protect buyers from having to pay twice, the statute must be construed with this in mind. The dissent concluded that Cimpl knew it was dealing with the Berwalds fronted by C \& M Dairy. ${ }^{269}$ Also the dissent concluded that Cimpl, the buyer, could have easily determined that C \& M Dairy was a fictitious name. ${ }^{270}$ After all, all of the sales seem to have been made by Berwalds. Yet, it is important to note that the definition of buyer in the ordinary course under 7 U.S.C. $\S 1631(c)(5)$

\footnotetext{
subordinations from lienholders a second time. If the ASCS search fails to discover all lienholders who filed before the ASCS, it will pay these lienholders. Finally, note that if the buyer makes a mistake twice, the CCC's will not permit the buyer to buy commodities subject to its perfected security interest for one year. In short, CCC would comply with $\S 1631$ and will not waive its interest.

The CCC's theory apparently was that CCC would not let the farmer participate in the loan program until it had obtained lien waivers from all secured creditors who had filed a UCC-1, and therefore it has priority as to the grain sealed and used as collateral for the loan. This policy applied to buyers of grains, oilseeds, and rice subject to a perfected security interest of the CCC. The CCC would indemnify the buyers if a creditor holding a superior interest to the $\mathrm{CCC}$ were to sue the buyer. It will only indemnify for the amount of grain specified in CCC Form CCC-681-1.

266. U.C.C. \$ 9-503(c).

267. 7 U.S.C. $\S 1631(4)(H)$. See also supra notes $195-96$ and accompanying text.

268. Cimpl, 754 N.W.2d at 12.

269. Id. at 21 (Sabers, J., dissenting).

270. Id.
} 
does not require good faith on the part of the buyer and knowledge is irrelevant. Also, 7 U.S.C. $\S 1631$ has no general good faith requirement.

The other issue the court had to consider was the requirement in 7 U.S.C. $\S 1631$ that for a buyer of farm products to take free of a security interest, the seller must have created the security interest. Section 1631(d) provides in part: "a buyer who in the ordinary course of business buys a farm product from a seller engaged in farming operations shall take free of a security interest created by the seller...."271 This issue had never been confronted when the debtor-seller was a d.b.a. The majority rejected the Minnesota Supreme Court's holding in Fin-Ag, Inc. v. Hufnagle, Inc. ${ }^{272}$ that sellers fronting for the debtor could not be treated as sellers who had created the security interest. ${ }^{273}$ The Hufnagle court held that the term "seller" should mean the same for the notice requirement as for the requirement that the seller must have created the security interest. ${ }^{274}$ Thus, in Hufnagle the sellers were children or employees of the debtor and they were not listed on the master list, and therefore the buyer did not have notice. Therefore, because they had not created the security interest, the seller had not created the security interest.

The majority of the South Dakota Supreme Court purported to distinguish a fronting situation from a d.b.a situation, but really rejected the Minnesota Supreme Court's analysis. It argued that the debtors here, the Berwald brothers themselves did not transfer the farm products to a real person for later sale but utilized the d.b.a. entity to sell the cattle. ${ }^{275}$ "Therefore, for purposes of the created by the seller limitation, Berwalds cannot be separated from the acts of their d.b.a. C \& M Dairy."276 Section 1631 does not define seller and the majority looked to the UCC and cases dealing with UCC section 9-320's requirement that the seller must have created the security interest. ${ }^{277}$ Using this background, it

271. 7 U.S.C. $\S 1631(\mathrm{~d})$.

272. 720 N.W.2d 579 (Minn. 2006).

273. Cimpl, 754 N.W.2d at $13-15$.

274. Hufnagle, 720 N.W.2d at $586-87$.

275. Cimpl, 754 N.W.2d at 12-13. It should be noted that the some of the cattle were sold by the father of the brothers. The court does not deal with what legal relationship, if any, existed between the brothers and the father. For example, was the father an employee or an agent of the partnership?

276. Id. It must be noted that the majority rejects Hufnagle for reasons that are not very clear to me. It says that, unlike Hufnagle, no collusion on the part of the buyer exists. It is unclear how the majority finds collusion existed in Hufnagle. Furthermore, the majority concludes that Hufnagle was also premised upon an incorrect assumption dealing with the notice and the sale by an agent of an undisclosed principal. The dissent rejects this.

277. Id. at 8. Cf. 9 C.F.R. $\S 205.211$ (2010) (specifically incorporating the UCC cases dealing 
concluded that the Berwalds did business under the name C \& M Dairy. It stated: "Legally, C \& M Dairy was the Berwalds."278 Because C \& M Dairy was the alter ego of the Berwalds, and because the Berwalds created the security interest, C \& M Dairy must be regarded as the seller who created the security interest.

For purposes of notice to the seller, form controlled - not substance. For the requirement that the seller must create the security interest, by using the "alter ego" the majority in effect used substance over form. But what about the minor error rule? The EFS was correct except the d.b.a. name was omitted. How can this be seriously misleading if the majority treats C \& M Dairy as the alter ego of the Berwalds? For seller purposes, how is it possible to say that the buyer did not have notice? It was simple for the majority $-\mathrm{C} \& \mathrm{M}$ was not listed on the EFS!

The other South Dakota case that deserves attention is Fin-Ag, Inc. v. Pipestone Livestock Auction Market. ${ }^{279}$ This case, in part, involved the sale of cattle subject to a perfected security interest. 7 U.S.C. $\S 1631$ treats a commission merchant selling farm products subject to a security interest in the same manner as a buyer of farm products subject to a perfected security interest. ${ }^{280}$ Like in Cimpl, the Berwald brothers executed a security agreement granting Fin- $\mathrm{Ag}$ a security interest in farm products. ${ }^{281}$ A FS and EFS were filed with the Secretary of State. ${ }^{282}$ The FS showed the debtor as "Berwald Partnership" and described the collateral as all livestock and farm products. ${ }^{283}$ The EFS here, according to the majority, listed the debtors as Berwald Partnership, Calvin Berwald, Michael Berwald, Kimberly Berwald, and Sokota Dairy, LLC as debtors. ${ }^{284}$ The EFS covered farm products such as dairy cattle and milk and listed the debtor as the "Berwald Partnership." ${ }^{285}$ The security agreement required joint-payee checks when any cattle were sold. ${ }^{286}$ Most of the cattle sold through the sale barns were sold under the name of C \& M Dairy which is the d.b.a. used by two of the Berwald brothers

\footnotetext{
with scope of the farm products rule under the prior version of Article 9's definition of farm products under U.C.C. § 9-307). See also supra note 186.

278. Cimpl, 754 N.W.2d at 16.

279. 754 N.W.2d 29 (S.D. 2008), cert. denied 129 S. Ct. 2859 (2009).

280. 7 U.S.C. $\S 1631(\mathrm{~g})$.

281. Pipestone Livestock, 754 N.W.2d at 34.

282. Id.

283. Id. at $34 \mathrm{n} .2$

284. Id. at 34 .

285. Id.

286. Id. at 35 .
} 
to buy and sell cattle. ${ }^{287}$ After a check of the EFS registry did not disclose C \& $\mathrm{M}$, single payee checks were issued to $\mathrm{C} \& \mathrm{M} .^{288}$ Fin-Ag brought a conversion action against the sale barns. ${ }^{289}$

The majority applied the reasoning of Cimpl and held that the sale barn took the cattle free of Fin-Ag's security interest even though the debtors used an assumed business name-it was their alter ego. ${ }^{290}$ However, as to the sales where debtor identified himself as owner, the sale barn was not protected. Debtor was listed on the EFS and the sale barn was required to cut a joint-payee check and it did not. ${ }^{291}$

The court also considered whether 7 U.S.C. $\S 1631$ protected the buyer when buyer retained the proceeds of a sale and set off against the proceeds the debtor's antecedent debt with the seller or commission merchant or commission agent. ${ }^{292}$ The court held that $\S 1631$ did not protect the sale barn to the extent that it applied proceeds of the cattle sales to debtor's antecedent debt with the sale barns. ${ }^{293}$ Put another way, $\S 1631$ only protects the buyer in ordinary course who pays the seller the proceeds and is not acting like a creditor. Thus, a buyer, who is protected by $\S 1631$ as to the purchase of the farm products subject to a security interest, may have a problem if it sets off the amount of the proceeds against seller's pre-existing debt to the buyer. Article 9, not the federal rule, determines who has priority to the proceeds. Specifically, the court stated:

The application of proceeds to a preexisting debt is not protected by the FSA because the buyer is not acting as a "buyer in ordinary course."

"Buying" does not include receiving goods or document of title under a preexisting contract as security "for or in total or partial satisfaction of a money debt," thereby excluding "attaching creditors and others who take goods in satisfaction of preexisting debts" from the definition of "buyer in ordinary course.,"

Now, the issue is who has priority under Article 9? The key is what is the status of the parties under Article 9. The buyer can be an

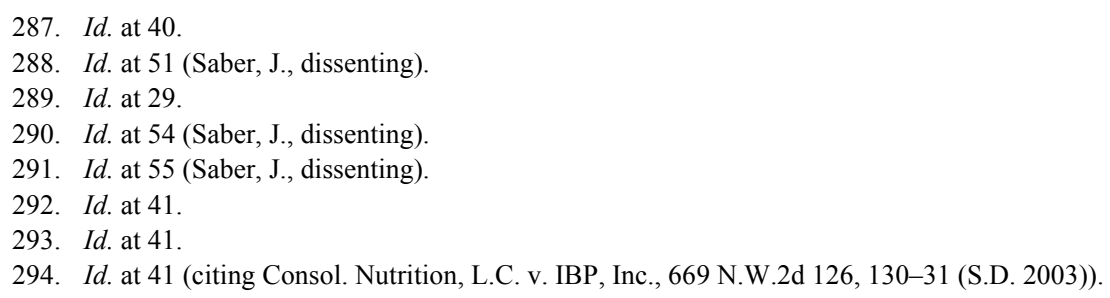


unsecured creditor, secured creditor, ${ }^{295}$ or have an agricultural lien. ${ }^{296}$ If a creditor had a security interest in the farm products under UCC sections 9-315(a)(2), the security interest continues in identifiable proceeds of the farm products. Perfection of proceeds is covered in section 9-315(c)-(d) and the priority rules resolving conflicts between two secured creditors are found in section 9-322(a)-(b). Of course, an unsecured creditor loses to a secured creditor. ${ }^{297}$

The last point ${ }^{298}$ to be discussed concerning the South Dakota cases is that the United States Supreme Court denied certiorari in June 2009. ${ }^{299}$ After the certiorari petition was filed, the Court invited the Solicitor General to express the government's view of the issue raised under 7 U.S.C. $\S 1631$. In her brief, the Solicitor framed the issue as

Whether a buyer of farm products in the ordinary course of business is entitled to the protections of the Food Security Act of 1985, 7 U.S.C. $\S$ 1631(d), and thus to take purchased property free of a security interest created by the seller, where the creditor fails to include the debtorseller's "doing business as" name on its financing statement, as required under state law.

295. See U.C.C. § 9-102(a)(72)(A)

296. See $\S 9-102(a)(5)$. Since 2001 , Article 9 rules of perfection, priority, and default and enforcement apply to agricultural liens. $\S \S 9-109$ (a)(2), -308(b), -322(a), -601 cmt. 7, -606. The default rules apply to a secured party which is defined to include a holder of an agricultural lien. See $\S 9-102(\mathrm{a})(72)(\mathrm{B})$.

Article 9 does not appear to deal with proceeds of the lien. See § 9-302 cmt. 2, -315(a)(2). These articles do not refer to agricultural liens and proceeds whereas UCC section 9-315(a)(1) specifically refers to an agricultural lien following the sale of the collateral subject to the agricultural lien.

Again, remember Kansas excluded agricultural liens from the coverage of the Kansas version of Article 9. It is covered by other statutes. See, e.g., KAN. STAT. ANN. §§ 2-1319, 2-3007, 34-239, $58-201,58-203,58-204,58-207,58-218,58-220$, 58-221, 58-241, 58-242, 58-2524, 58-2525, 582526, 58-2527, 58-2528 (2009) (dealing with agricultural liens).

297. U.C.C. § 9-201(a) (2009); see § 9-317(a) (demonstrating secured creditors superior claim by negative inference).

298. Two other issues that were raised in the South Dakota cases must be noted. One concerned the effectiveness of the EFS filed by creditors. The court did not address an issue raised by the sale barns that the EFS was defective because it described the collateral as "dairy cattle" and some of cattle purchased were beef cattle. Pipestone Livestock, 754 N.W.2d at 35; Fin-Ag, Inc. v. Cimpl's, Inc., 754 N.W.2d 1, 4 (S.D. 2008). It did recognize that 7 U.S.C. $\$ 1631(\mathrm{c})(4)(H)$ contains a minor error provision but the analysis is complicated by the USDA regulations found in 9 C.F.R $\S \S$ 205.106, 205.202. See Pipestone Livestock, 754 N.W.2d at 42-43.

The other issue involved whether the secured creditor has sufficiently shown that the sales were unauthorized. A divided court held that an implied authorization to sell is not recognized as a defense to a state law conversion action. Id. at 44-45.

299. Fin-Ag, Inc. v. Pipestone Livestock Auction Mkt., Inc., 129 S. Ct. 2859 (2009).

300. Brief for United States as Amicus Curiae, Fin-Ag, Inc. v. Pipestone Livestock Auction Mkt., Inc., 129 S. Ct. 2859 (2009) (No. 08-576), 2009 WL 1464949, at 3. 
The Solicitor argued in her brief that a state has the authority under 9 C.F.R. $\S 205.103(b)$ to establish different rules for debtor's names than are required under Article 9. ${ }^{301}$ The Solicitor's brief goes on to note that South Dakota, according to the USDA, is the only state with a 7 U.S.C. § 1631 central filing system that requires that a d.b.a. name be listed. ${ }^{302}$ The Solicitor argued that this uniqueness justified the denial of certiorari. $^{303}$

The requirement of 7 U.S.C. $\S 1631(d)$ that the seller must have created the security interest remains inconsistent with the South Dakota decision. The use of trade names has been rejected by the current version of Article 9 as being too uncertain. UCC section 9-503(c) states that "[a] financing statement that provides only the debtor's trade name does not sufficiently provide the name of the debtor."304 Again, remember that the legal name of the debtor under Article 9 is not the d.b.a. name.

The third South Dakota case, Fin-Ag, Inc. v. Watertown Livestock Auction, Inc. ${ }^{305}$ decided on the same day as the two South Dakota cases discussed above, also involved the sale of cattle subject to a perfected security interest. ${ }^{306}$ The case was reversed and remanded to be handled in a manner consistent with the court's determinations in Fin-Ag, Inc. v. Cimpl's, Inc. ${ }^{307}$ and Fin-Ag, Inc. v. Pipestone Livestock Auction Market, Inc. ${ }^{308}$

The South Dakota cases involved conversion actions filed by a secured creditor who asserted conversion occurred when the buyer purchased farm products that were subject to a perfected security interest and did not remit the proceeds to the secured party. ${ }^{309}$ UCC section 9601(a)(1) provides that upon default, a secured party "may reduce a claim to judgment, foreclose, or otherwise enforce the claim, security interest, or agricultural lien by any available judicial procedure . ..."310 A state conversion action is not a specified remedy in UCC section 9601 , but it seems clear that it would be covered by the right to enforce the claim by "any available judicial procedure." Whether there is an

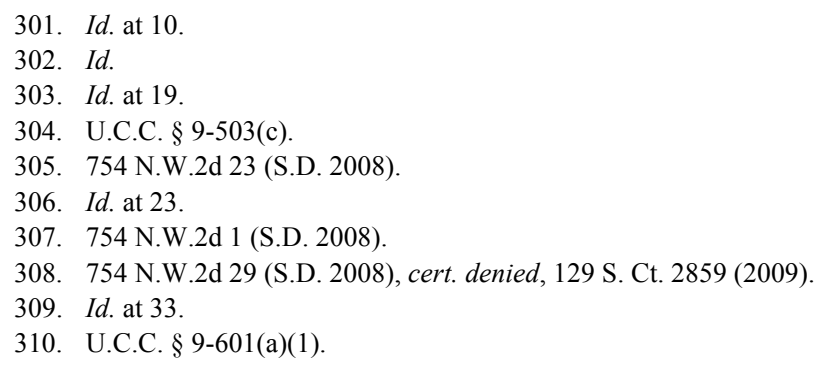


implied conversion action created by Article 9 is an interesting question. It is also unclear whether Article 9 creates an implied federal private right of action under 7 U.S.C. $\S 1631^{311}$ and if a federal court would have jurisdiction over such a claim. ${ }^{312}$

The elements that must be established in a conversion action vary from state to state. Some of the requirements for a South Dakota conversion action were discussed in Pipestone. ${ }^{313}$ If conversion occurs what are the damages which turn on the value of the collateral converted? One recent decision holds that the value of the property converted is to be determined by the jury. ${ }^{314}$

311. While 7 U.S.C. $\S 1631$ is purely a priority rule in Article 9 terminology, it does give protection to buyers of farm products subject to a security interest and commission merchants selling farm products subject to a security interest. This protection can probably be called a federally created right and provide a defense to a claim by a secured creditor for conversion. On the other hand, $\S 1631$ provides that a secured party's state-created security interest is not cut off when appropriate notice is given to the buyer or commission merchant. The statute is silent as to how a secured party is to enforce its security interest against the buyer. That is, no specific remedy is set forth. Thus, the question is whether Congress intended to create a private cause of action for damages. The statute does provide that if the debtor sells to a buyer or a commission merchant not listed in the security agreement, the debtor "shall be fined $\$ 5,000$ or 15 per centum of the value or benefit received for such farm product described in the security agreement, whichever is greater." 7 U.S.C. § 1631(h)(3).

The Supreme Court has struggled with the issue of an implied federal private cause of action. A landmark case is Cort v. Ash, in which the Court articulated a four-factor test for determining whether a private right of action is implicit in a federal statute not expressly providing for one. 422 U.S. 66, 78 (1975). Cort has not been overruled, but recent decisions indicate that the second factor requiring some concrete evidence that Congress intended to create a federal remedy is now the sole test. See Middlesex County Sewage Auth. v. Nat'l Sea Clammers Ass'n, 453 U.S. 1, 13 (1981) ("[t]he key to the inquiry is the intent of the Legislature"); Transamerica Mortgage Advisors, Inc. v. Lewis, 444 U.S. 11, 23-24 (1979); Touche Ross \& Co. v. Redington, 442 U.S. 560, 575 (1979) (Cort factors not entitled to equal weight); Bruce A. Boyer, Howard v. Pierce: Implied Causes of Action and the Ongoing Vitality of Cort v. Ash, 80 Nw. U. L. REV. 722, 727-28 (1985).

312. Cases involving 7 U.S.C. $\S 1631$ present a federal jurisdiction issue that can arise in a variety of ways. For example, the issue may present itself when the secured creditor files a conversion action in federal court asserting the buyer or commission merchant failed to protect the creditor's right to receive the proceeds from collateral in which it had a perfected security interest of which buyer had notice, or when the secured party files a conversion action in a state court and the buyer seeks to remove the case to federal court. While uncertainties may exist concerning federal court jurisdiction, it is clear that the state courts have jurisdiction, regardless of whether there is federal jurisdiction. The state courts clearly have concurrent jurisdiction over issues concerning 7 U.S.C. $\S 1631$ because there is nothing in the statute or its legislative history indicating that Congress intended to make it an area that could only be litigated in the federal courts. In other words, there is no indication that exclusive federal jurisdiction was intended.

Federal jurisdiction can be predicated on (1) diversity of the parties or (2) a federal question. 28 U.S.C. $\S \S 1331,1332$. Federal courts "have original jurisdiction of all civil actions arising under the Constitution, laws, or treaties of the United States." 28 U.S.C. $§ 1331$. Whether a suit based in part on 7 U.S.C. $\$ 1631$ raises a federal question turns on what "arising under the laws of the United States" means. "Arising under" is not self-defining. See Merrell Dow Pharm., Inc. v. Thompson, 478 U.S. 804 (1986); Smith v. Kansas City Title \& Trust Co., 255 U.S. 180 (1921).

313. Fin-Ag., Inc. v. Livestock Auction Market, Inc., 754 N.W.2d 29, 44 (S.D. 2008).

314. Bartlett Milling Co. v. Walnut Grove Auction and Realty Co., 665 S.E.2d 478, 485 (N.C. 


\section{VIII.SALE OF FARM PRODUCTS SUBJECT TO AN UNPERFECTED SECURITY INTEREST}

In most transactions involving the sale of farm products subject to a security interest, the security interest is perfected. What law governs when the security interest is unperfected? Does 7 U.S.C. $\S 1631$ control or does UCC section 9-317(b) control, which deals with buyer of goods subject to an unperfected security interest? UCC section 9-317(b) provides: "Except as otherwise provided in subsection (e), a buyer of . . . goods ... takes free of a security interest or agricultural lien if the buyer gives value and receives delivery of the collateral without knowledge of the security interest or agricultural lien and before it is perfected." 315

Who wins if the buyer has actual knowledge of the unperfected security interest before delivery but does not receive the required proper notice under 7 U.S.C. § 1631(d)-(e)? Under UCC section 9-317(b), a buyer takes subject to the unperfected security interest because it had knowledge before delivery. ${ }^{316}$ The result is the opposite under the federal rule because a buyer takes free unless it receives the appropriate notice. $^{317}$

Does the federal rule preempt the UCC for all conflicts between buyers and secured parties whether the secured party is perfected or not? 7 U.S.C. $§ 1631(d)$ provides:

Except as provided in subsection (e) of this section and notwithstanding any other provision of Federal, State, or local law, a buyer who in the ordinary course of business buys a farm product from a seller engaged in farming operations shall take free of a security interest created by the seller, even though the security interest is perfected; and the buyer knows of the existence of such interest.

It appears that $\S 1631$ preempts Article 9's treatment of any transaction involving the sale to a buyer in ordinary course of farm products subject to a security interest. This section says the rule applies notwithstanding state law. ${ }^{318}$ This would arguably include all of Article 9. If it does, Article 9 is preempted, unless this section treats unperfected security interests differently from perfected ones. It appears that the notice requirements apply to unperfected security interests as well

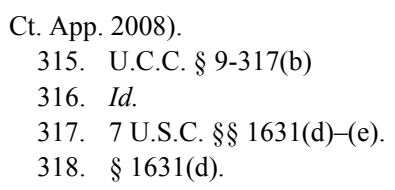


because the language simply refers to a security interest created by the seller. $^{319}$

\section{PURCHASERS OF FARM PRODUCTS AND AgRicUltural LIENS}

\section{A. Section 1631 and Agricultural Liens Under the UCC}

Another transaction that raises a scope question about 7 U. S. C. $\S$ 1631 concerns sales of farm products subject to a statutory lien. Section 1631 does not apply to involuntary liens. Section 1631(d) simply refers to a security interest "created by the seller." An agricultural lien under UCC section 9-102(a)(5) is created by state statute not by agreement. Thus, conflicts between a holder of an agricultural lien and a purchaser are determined by law other than 7 U.S.C. $\S 1631$.

Some states, like Minnesota, have enacted $\S 1631$-type statutes for agricultural liens. Minnesota has two specific statutes dealing with the sale of farm products subject to a statutory lien. ${ }^{320}$ These statutes essentially apply the $\S 1631$ requirements to the statutory liens. Thus, the Minnesota and South Dakota cases discussed above are relevant to conflicts between a lien holder and a buyer of farm products subject to a perfected statutory lien.

In states that do not have a Minnesota-type statute applicable to agricultural liens, Article 9 controls. Section 9-315(a)(1) provides that an agricultural lien continues in collateral notwithstanding sale or lease of the collateral unless a provision in Article 9 or in UCC section 2403(2) provides otherwise or "the secured party authorized the disposition free of the . . agricultural lien.",321

Remember that UCC section 9-320 provides "a buyer in ordinary course of business, other than a person buying farm products from a person engaged in farming operations, takes free of a security interest created by the buyer's seller, even if the security interest is perfected and the buyer knows of its existence." Agricultural liens are not mentioned and the definition of a security interest does not include an agricultural lien. ${ }^{322}$ However, UCC section 9-317(b) provides in part "a buyer... of . . goods . . . takes free of a security interest or agricultural lien if the buyer gives value and receives delivery of the collateral without

\footnotetext{
319. $\S 1631(\mathrm{~g})(2)(\mathrm{A})$.

320. See MinN. STAT. $\S \S 336 A .15$ to .16 (2007).

321. See supra notes 136-39 and accompanying text.

322. U.C.C. $\S \S 1-201(\mathrm{~b})(35) ; 9-102(\mathrm{a})(5) ; c f . \S 9-102(\mathrm{a})(72)(\mathrm{B})$ (defining a secured party as "a person who holds an agricultural lien”).
} 
knowledge of the security interest or agricultural lien and before it is perfected." The negative inference is that, if an agricultural lien holder has perfected its lien, the buyer takes subject to it. Thus, combining UCC section 9-317(b) with section 9-315(a)(1), the agricultural lien is not cut off by a sale to a buyer in the ordinary course.

\section{B. Kansas's Approach to Sale of Farm Products Subject to a Statutory Lien}

One of the most significant 2001 revisions of Article 9 involved nonpossessory liens in agricultural products. For the first time, a nonpossessory statutory lien defined as an "agriculture lien" was made subject to the uniform version of Article 9's perfection, priority, and enforcement rules. Every state except Kansas included this coverage when the UCC was enacted. The Kansas Legislature excluded from the coverage of Article 9 nonpossessory agricultural liens in farm products created by the statutory liens listed in K.S.A. sections 84-9-102(a)(76) \& 9-102(a)(5). Also see K.S.A. section 84-9-201(b) which purports to say that Article 9 is subject to state statutes that create a different rule "including, but not limited to, K.S.A. section 2-1319, 2-2608, 2-3007, 34-239, 47-836, 58-201, 58-203, 58-204, 58-207, 58-218, 58-220, 58$221,58-241,58-242,58-2524,58-2525,58-2526,58-2527,58-2528$, and 84-7-209."323

Kansas has no general statute dealing with the sale of farm products subject to a statutory lien. Kansas does have a statute dealing with landlord liens and purchasers from tenants who have not paid the rent. Kansas statutes dealing with landlord liens have not been amended since 1923 and provide:

Kan. Stat. Ann. §58-2524. Rent as lien on crop. Any rent due for farming land shall be a lien on the crop growing or made on the premises. Such lien may be enforced by action and attachment therein, as hereinafter provided.

323. KAN. STAT. ANN. § 84-9-201(b). Creditors thinking about or taking a security interest in farm products in Kansas have a potpourri of statutory liens that have no uniformity as to creation, perfection, priority, and enforcement. This uncertainty also applies to the purchasers of farm products.

In Kansas, each statute creating an agriculture lien and cases interpreting it must be checked to determine how it is created, when it attaches, when it is perfected, when it has priority over other creditors or buyers and how the lien is enforced. A number of law review articles examine agricultural financing and liens under revised Article 9. See, e.g., Meyer, Unique Treatment, supra note 13 and articles cited therein.

324. Kan. Stat. ANN. § 58-2524. 
Kan. Stat. Ann. §58-2525. Same; lessor's remedies when rent payable in share of crop. When any such rent is payable in a share or certain proportion of the crop, the lessor shall be deemed the owner of such share or proportion, and may, if the tenant refuses to deliver the lessor such share or proportion, enter upon the land and take possession of the same, or obtain possession thereof by action of replevin. ${ }^{3}$

Kan. Stat. Ann. §58-2526. Recovery of rent from purchaser of crop. The person entitled to the rent may recover from the purchaser of the crop, or any part thereof, with notice of the lien the value of the crop purchased, to the extent of the rent due and damages.

Issues concerning the sale of farm products produced on rented land can arise in at least two distinct situations. One situation arises when the land is cash rented. A conflict arises here when the tenant does not pay the rent and sells the crop produced on the rented land to a local elevator. Under K.S.A. section 58-2524, the landowner has a lien on the crops and may recover the cash rent owed from the elevator. Also, K.S.A. section 58-2526 allows the unpaid landowner to collect from the purchaser with notice of the lien. To be successful, the landowner must show the rent was unpaid, the crops were produced on the rented land, and the purchaser had notice of the lien. The landlord has the burden of establishing that the purchaser had notice. ${ }^{327}$ Unlike in the UCC, no statutory definition of notice exists. Thus, courts have to determine if something less than actual knowledge will suffice. The old cases seem to indicate that constructive notice is possible. ${ }^{328}$ Courts might analogize to the UCC's definition of notice. ${ }^{329}$

A second situation arises with a crop-share lease. The tenant sells all of the crops without the consent of the landowner. Here it would appear that landowner does not have to use K.S.A. section 58-2526. K.S.A. section 58-2525 seems to say that under a crop-share lease, the landowner is deemed to be the owner of the portion of crops treated as rent. For example, if the crop-share lease is one-third to landowner and two-thirds to tenant, the land owner is deemed to be the owner of onethird of the crop produced on the rented land. No mention is made of a purchaser of the landowner's crop-share. The only remedy discussed is that the land owner is authorized to enter upon the land and seize its

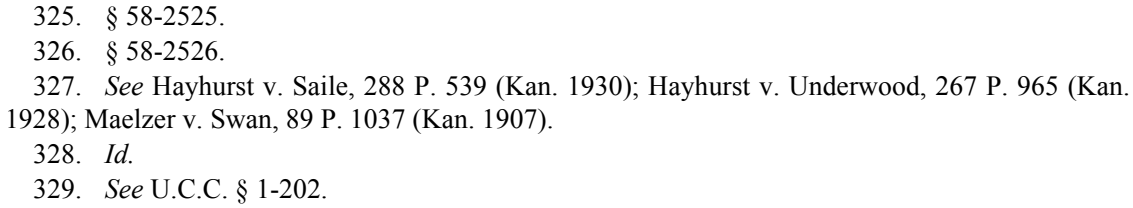


share of the crop; it does not discuss a remedy against a purchaser. When the tenant sells all of the crops produced on the rented land, part of those crops belonged to the landowner. The tenant was not authorized to sell them. The tenant has in effect stolen the crops belonging to landowner. The general rule is that a thief has no title or void title and the purchaser gets only the title that the seller had or had the power to transfer. ${ }^{330}$ Thus, absent some estoppel argument or maybe an entrustment argument under UCC section 2-403(2), the purchaser will lose to landowner. ${ }^{331}$ The issues dealing with leases could be avoided very easily when a cash lease is involved. Landowner simply gets the cash at the beginning of the lease.

330. See, e.g., U.C.C. § 2-403(1).

331. See supra notes $138-83$ and accompanying text. 